\title{
Petrogenesis of macrocrystic and aphanitic intrusions in Mesoproterozoic diamondiferous pipe 2 kimberlite, Wajrakarur kimberlite field, eastern Dharwar craton, southern India
}

\author{
AShish N. Dongre, ${ }^{1 *}$ N. V. Chalapathi RAO ${ }^{2}$ and M. MALANDKAR ${ }^{1}$ \\ ${ }^{1}$ Post Graduate Department of Geology, Institute of Science, Aurangabad-431004, India \\ ${ }^{2}$ Centre for Advanced Study, Department of Geology, Banaras Hindu University, Varanasi-221005, India
}

(Received September 26, 2013; Accepted August 9, 2014)

\begin{abstract}
Mesoproterozoic Pipe 2 kimberlite intruding granitic gneisses in the Wajrakarur kimberlite field (WKF) of Eastern Dharwar craton, southern India, is one of the first discovered pipes from this field. The two different intrusions belonging to coherent facies are observed in this kimberlite which are texturally distinct i.e., macrocrystic (with abundant macrocrysts) as well as aphanitic (devoid of or very fewer macrocrysts). Petrographic observations give evidence of presence of veined metasomatic mantle in the source region. Distinct geochemical variation is observed between macrocrystic ( $\mathrm{Mg \#} 75.4-$ 76.6, $\mathrm{SiO}_{2}:$ 34.3-35.4 wt\%, $\mathrm{MgO}: 18.7-20.4 \mathrm{wt} \%$ ) and aphanitic samples (Mg\# 74.7-75.5, $\mathrm{SiO}_{2}: 30.4-31.8 \mathrm{wt} \%, \mathrm{MgO}$ : $\sim 21 \mathrm{wt} \%$ ), furthermore aphanitic samples are relatively more enriched in trace and rare earth elements. Geochemical studies point out that aphanitic and macrocrystic varieties of Pipe 2 kimberlite to be products of the same mantle source but have experienced different evolutionary histories. The inferred primary magma of Pipe 2 kimberlite (for both aphanitic and macrocrystic) is suggested to have a composition of $\sim 33 \mathrm{wt} \% \mathrm{SiO}_{2}, \mathrm{Mg \#} \sim 75.6$ and $\sim 60$ ppm Ni. Pipe 2 primary magma can be derived by using forward melting model assuming $\sim 1 \%$ partial melting of a source enriched in light REE by a factor of $\sim 11 \mathrm{x}$ chondrite and almost chondritic heavy REE with $2 \%$ residual garnet. Differences between aphanitic and macrocrystic varieties in their chondrite normalized REE abundance patterns can be explained by about $5 \%$ crystal fractionation of primary magma and not by variations in the degree of partial melting. The primitive mantle normalized trace element patterns exhibit significant negative $\mathrm{K}, \mathrm{Sr}, \mathrm{P}, \mathrm{Ti}$ and $\mathrm{Hf}$ anomalies that are interpreted to be characteristic of the primary magma. Combined petrology and whole rock geochemistry including compatible and incompatible element abundances and their ratios confirm that Pipe 2 kimberlite intrusions are archetypal Group I kimberlites similar to other kimberlites of EDC and not lamproites.
\end{abstract}

Keywords: Wajrakarur kimberlite field, Eastern Dharwar craton, geochemistry, geochemical modeling, petrogenesis

\section{INTRODUCTION}

Kimberlites are complex potassium-bearing, ultramafic rocks having deep mantle origin. Although rare and volumetrically insignificant they invite considerable interest owing to their entrained mantle xenoliths (e.g., Gregoire et al., 2003) and xenocrysts such as diamonds (e.g., Rombouts, 2003) thereby constituting "windows to the Earth's mantle". Their extreme magma composition (low $\mathrm{SiO}_{2}$, high trace element and volatile contents) render an understanding of the melting processes undergone by their mantle source regions a challenging task.

Kimberlite bulk-composition is not straight forward to define because of (i) the frequent presence of mantle xenoliths, (ii) contamination with country rocks and (iii) its susceptibility to alteration. However, multiple pulses

\footnotetext{
*Corresponding author (e-mail: andongrey@gmail.com)
}

Copyright (c) 2014 by The Geochemical Society of Japan. of kimberlite magmas are reported to form several distinct geological units in the same pipe or intrusion (Sparks, 2013). Therefore, evolved kimberlites, which are poor in or devoid of macrocrysts, such as aphanitic varieties can give a true indication of the liquid path. Several studies investigated the trace element geochemistry of kimberlites with a view to constrain the petrogenetic processes involved in their evolution (e.g., Fraser and Hawkesworth, 1992; Tainton and McKenzie, 1994; Beard et al., 1998; Price et al., 2000; Le Roex et al., 2003; Chalapathi Rao et al., 2004; Harris et al., 2004; Becker and Le Roex, 2006; Coe et al., 2008; Tappe et al., 2011, 2013; Toyama et al., 2012).

The Mesoproterozoic kimberlites are most abundant in the Eastern Dharwar craton (EDC) of southern India (Chalapathi Rao et al., 2013). In fact, the Indian cratons reportedly host the largest yet known number of Mesoproterozoic kimberlites in the world (Haggerty and Birkett, 2004; Chalapathi Rao and Srivastava, 2009) and offer an excellent opportunity to study and understand 


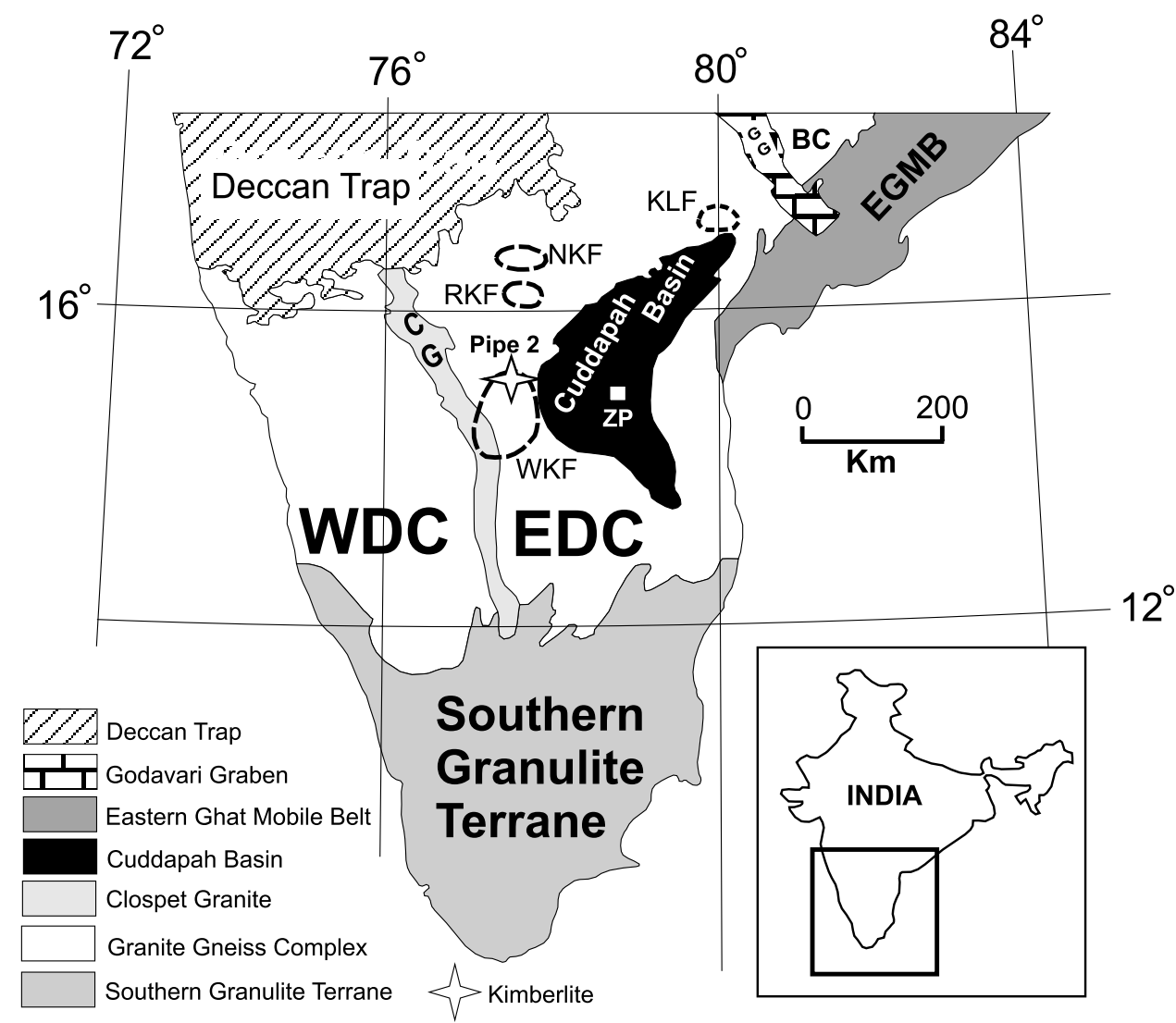

Fig. 1. Geological map of southern India showing location of Pipe 2 kimberlite modified after Patel et al. (2009). EDC, Eastern Dharwar craton; WDC, Western Dharwar craton; BC, Bastar craton; EGMB, Eastern Ghat Mobile belt; CG, Clospet granite; GG, Godavari graben; NKF, Narayanpet kimberlite field; RKF, Raichur kimberlite field; WKF, Wajrakarur kimberlite field; KLF, Krishna lamproite field; ZP, Zangamrajupalle lamproite.

the composition, nature and evolution of the Proterozoic lithospheric mantle prior to the make up of the Gondwana supercontinent. Pipe 2 kimberlite situated $2.5 \mathrm{~km}$ east of Wajrakarur is a part of the well known Wajrakarur kimberlite field (WKF) of Eastern Dharwar craton, southern India (Chalapathi Rao et al., 2004). It actually consists of two intrusions Pipe 2 east and Pipe 2 west. Pipe 2 west has been an acknowledged centre of detailed petrological studies due to its large and fresh outcrops whereas till date such studies have not been undertaken for Pipe 2 east intrusion. Pipe 2 west is diamondiferous (Rau et al., 2005) whereas no such information is available for Pipe 2 east. Two textural variants of kimberlites belonging to coherent facies (i.e., macrocrystic and aphanitic) are recognized for first time within this pipe. The occurrence of these two texturally different intrusions only in Pipe 2 kimberlite in the Wajrakarur area makes it a unique occurrence amongst $\sim 100$ kimberlites in Eastern Dharwar craton. Based on mineralogical studies this kimberlite was speculated to be an unusual lamproite like intrusion and not considered to be a bona fide kimberlite (Reddy, 1987;
Kaur and Mitchell, 2013). Present paper details the petrology and geochemistry of both the intrusions of this Mesoproterozoic diamondiferous kimberlite pipe from Wajrakarur field with the objective of evaluating their petrogenesis and constraining the composition of source magma(s).

\section{Geological Setting}

The Eastern Dharwar craton (EDC) of southern India exposes a granite-greenstone terrain composed predominantly of greenstone belts, gneisses, granitoids, late-topost tectonic intrusive granites (Closepet Granite and its equivalents of $\sim 2,500 \mathrm{Ma}$ ), platformal Proterozoic sedimentary basins (the Cuddapah, Kaladgi and Bhima basins) and widespread mafic dyke swarms. A recent review of the geology of the EDC has been provided by Naqvi (2005) and Ramakrishnan and Vaidyanadhan (2008).

Multidisciplinary surveys led by the Geological Survey of India and other agencies have resulted in the dis- 
covery of the several kimberlites in the EDC. These kimberlites are confined to four distinct fields, the Wajrakarur, the Tungabhadra, the Raichur and the Narayanpet kimberlite fields (Fig. 1). Majority of kimberlites in Wajrakarur kimberlite field are diamondiferous and occur in four distinct clusters: northern Wajrakarur-Lattavaram cluster (11 pipes); southeastern Chigicherla cluster (5 pipes); south-western Kalyandurg cluster (6 pipes) and newly discovered southern Timmasamudram cluster (4 pipes). The "pipes" are numbered in order of their discovery. The present study is centered on Pipe 2 kimberlite which is one of the earliest discovered pipes from WKF. It is situated $2.5 \mathrm{~km}$ east of Wajrakarur village (Fig. 1). The field setting and characters of its western and eastern lobes are outlined below:

Pipe 2 west kimberlite $\left(15^{\circ} 01^{\prime} 49^{\prime \prime}: 77^{\circ} 24^{\prime} 49^{\prime \prime}\right)$ is a crescent shaped body. The outcrop trend N75E-S75W and have a length of $380 \mathrm{~m}$ and a maximum width of 70 meters. It was discovered by Rao and Phadtre (1966). The rock is melanocratic, hard, compact, encloses fragments of country rocks and has well exposed outcrops. The processing of bulk materials in recent years by Geological Survey of India revealed that this pipe is diamondiferous.

Pipe 2 east kimberlite $\left(15^{\circ} 01^{\prime} 42^{\prime \prime}: 77^{\circ} 24^{\prime} 35^{\prime \prime}\right)$, located $100 \mathrm{~m}$ south of Pipe 2 west and constitutes its satellite body. It was discovered by Dhakate and Nayak (2002), and measures $500 \mathrm{~m} \times 120 \mathrm{~m}$ with NE-SW trend. Only preliminary studies have been carried out for this intrusion (Chalapathi Rao and Srivastava, 2009). The rock is fine grained, greenish colored and appears to be intensely altered.

\section{SAMPling AND ANALYTICAL TEChNiQUES}

As far as possible, the freshest outcrop samples were chosen for this study. Special care was taken to hand pick and removes all visible crustal, mantle xenoliths and calcite veins before subjecting them to geochemical studies. However inherent alteration in the samples due to the exposure of the kimberlites to tropical weathering for millions of years could not be eliminated.

Mineral chemistry analyses were obtained on a CAMECA SX100 and CAMECA SX5 Electron Probe Micro Analyzers (EPMA) installed at Geological Survey of India, Hyderabad and Indian Institute of Technology, Mumbai, India respectively. An acceleration voltage of $15 \mathrm{kV}$, beam current of $20 \mathrm{nA}$, beam diameter of $1 \mu \mathrm{m}$ and a counting time of $10 \mathrm{~s}$ were used.

Whole rock major and trace element analyses were carried out at the Activation Laboratories Ltd. Ancaster, Ontario, Canada. ICP-OES (Model: Thermo-JarretAsh ENVIRO II) was used to analyze major elements, whereas
ICP-MS (Model: PerkinElmer Sciex ELAN 6000) was used to determine trace and rare earth element (REE) concentrations. The precision is $<5 \%$ for all analyzed elements when reported at $100 \times$ detection limit. Standards, including SY-3, W-2, DNC-1, BIR-1 and STM-1 were run along with the samples to check accuracy and precision. The analytical procedure is detailed by Gale et al. (1999) and is also available in the Activation Laboratories Ltd. website (http://www.actlabs.com).

\section{Petrography and Mineral Chemistry}

The main Pipe 2 west body has typical inequigranular texture imparted by two populations of olivine and phlogopite set in a fine grained groundmass of microphenocrystal olivine, phlogopite, secondary serpentine, perovskite and apatite. Groundmass is poor in spinel and is preserved mostly in olivines. The pipe is richly macrocrystic and olivine macrocrysts are generally free from serpentinization whereas phlogopite macrocrysts are deformed and fractured along cleavage. This is a macrocrystic textural variety of Pipe 2 kimberlite. A very significant fabric is seen (Fig. 2) in which phlogopite vein traverses the olivine macrocryst. A solitary phlogopite macrocryst is deformed and resorbed by the kimberlite magma and probably a part of deformed mantle xenolith intersected by phlogopite vein. We interpret this as an evidence of modal mantle metasomatism of mantle by phlogopite-rich fluid.

On the other hand the satellite body i.e., Pipe 2 east is of very fine grained nature and very poor in macrocrysts. Sporadic occurrences of ilmenite macrocrysts are present. Groundmass is rich in abundant microphenocrysts of olivine, secondary serpentine, spinel and perovskite. Phlogopite is a rare or very poor groundmass phase in Pipe 2 east. It is poor in mantle xenoliths but rich in crustal xenoliths. The mineral chemistry data is presented in Table 1 .

\section{Phlogopite}

Phlogopite is a very rare phase in aphanitic Pipe 2 east whereas ubiquitous in macrocrystic Pipe 2 west intrusion where it occurs as a microphenocryst in groundmass and also as a large macrocrysts (Fig. 2). All the phlogopites are enriched in $\mathrm{TiO}_{2}$ (values upto $1.4 \mathrm{wt} \%$ ) and poor in $\mathrm{Al}_{2} \mathrm{O}_{3}(7-9.7 \mathrm{wt} \%)$ in macrocrystic variety whereas poor in $\mathrm{TiO}_{2}(0.61 \mathrm{wt} \%)$ and enriched in $\mathrm{Al}_{2} \mathrm{O}_{3}$ $(12.73 \mathrm{wt} \%)$ in aphanitic one. The phlogopite macrocrysts are appears to be less aluminous than the groundmass phenocrysts. In $\mathrm{TiO}_{2}$ versus $\mathrm{Al}_{2} \mathrm{O}_{3}$ plot (Fig. 3a) for discriminating between phlogopite from kimberlites and lamproites they show more affinity towards archetypal kimberlites than the lamproites and aillikites. $\mathrm{FeO}_{\mathrm{T}}$ content varies from $5.2-7.18 \mathrm{wt} \%$ in both the varieties. $\mathrm{K}_{2} \mathrm{O}$ 

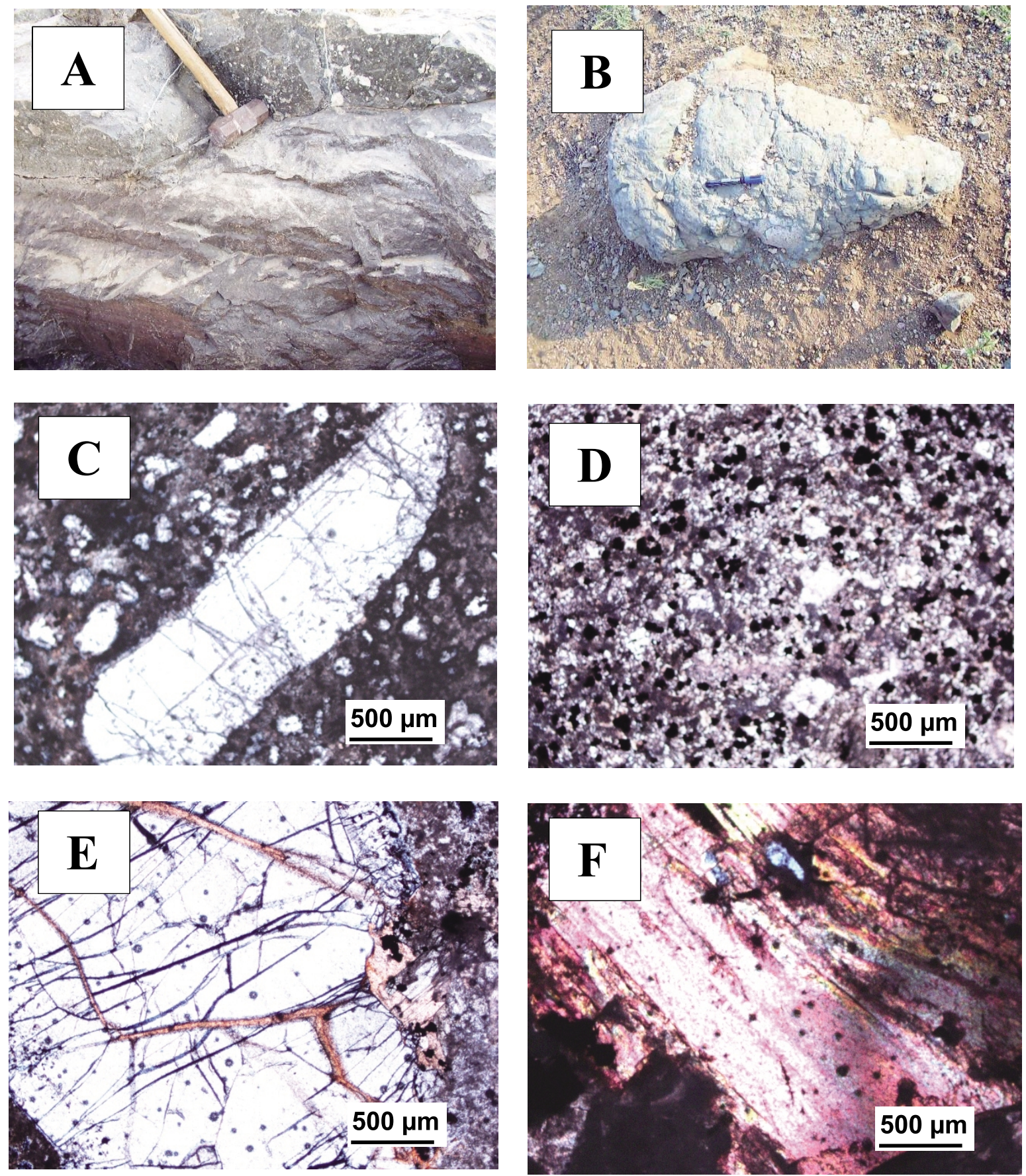

Fig. 2. Field photograph of Pipe 2 west kimberlite (A); Pipe 2 east kimberlite (B). Inequigranular macrocrystic texture in Pipe 2 west kimberlite imparted by subhedral to anhedral olivine, uncrossed nicols $(C)$; fine grained aphanitic texture in Pipe 2 east kimberlite, uncrossed nicols $(D)$; Olivine macrocryst intruded by phlogopite vein in Pipe 2 west kimberlite, uncrossed nicols $(E)$; deformed phlogopite macrocryst in Pipe 2 west kimberlite, crossed nicols $(F)$.

contents ranging upto $9.8 \mathrm{wt} \%$ which is close to ideal phlogopite composition. $\mathrm{BaO}$ content varies upto $1.8 \mathrm{wt} \%$. The phlogopite vein shows lower $\mathrm{K}_{2} \mathrm{O}$ (upto $8.7 \mathrm{wt} \%$ ), $\mathrm{TiO}_{2}$ (upto $0.3 \mathrm{wt} \%$ ) and $\mathrm{Al}_{2} \mathrm{O}_{3}$ (upto $6.2 \mathrm{wt} \%$ ) contents than the macrocrystic and aphanitic varieties.
Spinel

Spinels are omnipresent in kimberlites and occur as subhedral to strongly euhedral crystals in groundmass. Groundmass of macrocrystic variety is devoid of or very poor in spinels as compare to aphanitic samples. Gener- 
Table 1. Representative mineral analysis of phlogopite, spinels and olivine

\begin{tabular}{|c|c|c|c|c|c|c|c|c|c|c|c|c|c|c|}
\hline \multicolumn{15}{|l|}{ Phlogopite } \\
\hline Oxide (wt $\%$ ) & $\begin{array}{c}1 \\
\text { macro }\end{array}$ & $\begin{array}{c}2 \\
\text { macro }\end{array}$ & $\begin{array}{c}3 \\
\text { vein }\end{array}$ & $\begin{array}{c}4 \\
\text { vein }\end{array}$ & $\begin{array}{c}5 \\
\text { macro }\end{array}$ & $\begin{array}{c}6 \\
\text { macro }\end{array}$ & $\begin{array}{c}7 \\
\text { macro }\end{array}$ & $\begin{array}{c}8 \\
\text { vein }\end{array}$ & $\begin{array}{c}9 \\
\text { vein }\end{array}$ & $\begin{array}{c}10 \\
\text { vein }\end{array}$ & $\begin{array}{c}11 \\
\text { macro }\end{array}$ & $\begin{array}{c}12 \\
\text { macro }\end{array}$ & $\begin{array}{c}13 \\
\text { macro }\end{array}$ & $\begin{array}{l}\text { P2A* } \\
\text { apha }\end{array}$ \\
\hline $\mathrm{SiO}_{2}$ & 41.32 & 41.12 & 43.96 & 43.02 & 41.49 & 41.47 & 43.25 & 43.91 & 44.23 & 44.21 & 42.61 & 42.74 & 42.70 & 33.00 \\
\hline $\mathrm{TiO}_{2}$ & 1.46 & 1.26 & 0.33 & 0.34 & 1.27 & 1.42 & 1.00 & 0.21 & 0.29 & 0.27 & 1.48 & 1.40 & 1.26 & 0.61 \\
\hline $\mathrm{Al}_{2} \mathrm{O}_{3}$ & 9.71 & 9.24 & 5.84 & 6.02 & 9.66 & 9.55 & 7.00 & 6.28 & 5.58 & 5.72 & 7.18 & 7.12 & 8.57 & 12.73 \\
\hline $\mathrm{Cr}_{2} \mathrm{O}_{3}$ & 0.00 & 0.00 & 0.00 & 0.02 & 0.00 & 0.00 & 0.00 & 0.00 & 0.06 & 0.00 & 0.02 & 0.00 & 0.00 & 0.04 \\
\hline $\mathrm{FeO}$ & 5.33 & 5.30 & 9.23 & 11.74 & 5.20 & 5.26 & 6.54 & 7.89 & 10.93 & 10.58 & 6.55 & 6.53 & 5.51 & 7.18 \\
\hline $\mathrm{MnO}$ & 0.04 & 0.06 & 0.14 & 0.18 & 0.00 & 0.00 & 0.00 & 0.08 & 0.20 & 0.12 & 0.02 & 0.05 & 0.04 & 0.16 \\
\hline $\mathrm{MgO}$ & 23.95 & 23.75 & 24.63 & 24.28 & 24.15 & 23.99 & 23.85 & 25.76 & 24.27 & 24.54 & 23.29 & 23.20 & 24.11 & 24.40 \\
\hline $\mathrm{CaO}$ & 0.00 & 0.00 & 0.22 & 0.15 & 0.00 & 0.00 & 0.00 & 0.20 & 0.19 & 0.16 & 0.00 & 0.00 & 0.00 & 0.09 \\
\hline $\mathrm{Na}_{2} \mathrm{O}$ & 0.46 & 0.55 & 0.08 & 0.14 & 0.51 & 0.52 & 0.95 & 0.14 & 0.15 & 0.08 & 0.99 & 1.07 & 0.73 & 0.06 \\
\hline $\mathrm{P}_{2} \mathrm{O}_{5}$ & 0.00 & 0.01 & 0.01 & 0.00 & 0.01 & 0.00 & 0.00 & 0.00 & 0.00 & 0.00 & 0.00 & 0.00 & 0.00 & 0.14 \\
\hline $\mathrm{K}_{2} \mathrm{O}$ & 9.47 & 9.53 & 8.70 & 8.30 & 9.51 & 9.62 & 9.89 & 8.41 & 8.72 & 8.73 & 9.82 & 9.78 & 9.81 & 9.39 \\
\hline $\mathrm{BaO}$ & 1.76 & 1.74 & 0.10 & 0.01 & 1.81 & 1.68 & 1.08 & 0.09 & 0.09 & 0.12 & 1.07 & 1.12 & 0.92 & 0.00 \\
\hline Total & 93.50 & 92.56 & 93.24 & 94.21 & 93.60 & 93.51 & 93.56 & 92.97 & 94.71 & 94.54 & 93.04 & 93.01 & 93.64 & 87.80 \\
\hline
\end{tabular}

\begin{tabular}{lrrrrrrr}
\hline $\begin{array}{l}\text { Spinels } \\
\text { Oxide (wt\%) }\end{array}$ & $\begin{array}{c}1 \\
\text { apha }\end{array}$ & $\begin{array}{c}2 \\
\text { apha }\end{array}$ & $\begin{array}{c}3 \\
\text { apha }\end{array}$ & $\begin{array}{c}4 \\
\text { macro }\end{array}$ & $\begin{array}{r}\text { P2A* } \\
\text { apha }\end{array}$ & $\begin{array}{r}\text { P2A-1* } \\
\text { apha }\end{array}$ & $\begin{array}{r}\text { P2A-2* } \\
\text { apha }\end{array}$ \\
\hline $\mathrm{SiO}_{2}$ & 0.01 & 0.74 & 0.35 & 0.10 & 0.00 & 0.00 & 0.00 \\
$\mathrm{TiO}_{2}$ & 0.03 & 11.03 & 16.68 & 8.72 & 10.26 & 10.82 & 10.46 \\
$\mathrm{Al}_{2} \mathrm{O}_{3}$ & 0.02 & 2.97 & 4.50 & 0.27 & 7.38 & 1.13 & 7.31 \\
$\mathrm{Cr}_{2} \mathrm{O}_{3}$ & 0.36 & 0.04 & 0.04 & 0.15 & 29.90 & 0.23 & 27.40 \\
$\mathrm{Fe}_{2} \mathrm{O}_{3}$ & 47.86 & 36.96 & 30.16 & 46.68 & 19.63 & 46.97 & 22.03 \\
$\mathrm{FeO}$ & 39.54 & 34.63 & 31.58 & 39.01 & 15.04 & 36.27 & 15.86 \\
$\mathrm{MnO}$ & 0.33 & 0.88 & 1.08 & 0.79 & 0.62 & 0.77 & 0.57 \\
$\mathrm{MgO}$ & 8.67 & 5.24 & 7.86 & 3.23 & 16.87 & 2.16 & 16.97 \\
$\mathrm{CaO}$ & 0.05 & 0.40 & 0.38 & 0.06 & 0.19 & 0.47 & 0.11 \\
$\mathrm{Na}{ }_{2} \mathrm{O}$ & 0.00 & 0.04 & 0.03 & 0.05 & 0.00 & 0.00 & 0.00 \\
$\mathrm{~K}_{2} \mathrm{O}$ & 0.03 & 0.04 & 0.02 & 0.02 & 0.00 & 0.00 & 0.00 \\
$\mathrm{P}_{2} \mathrm{O}_{5}$ & 0.03 & 0.03 & 0.01 & 0.01 & 0.00 & 0.00 & 0.00 \\
$\mathrm{ZnO}$ & 0.08 & 0.16 & 0.06 & 0.02 & 0.00 & 0.00 & 0.00 \\
$\mathrm{Total}_{\mathrm{Fe}}^{2+} /\left(\mathrm{Fe}{ }^{2+}+\mathrm{Mg}\right)$ & 97.00 & 93.15 & 92.75 & 99.09 & 99.89 & 98.82 & 100.71 \\
$\mathrm{Ti} /(\mathrm{Ti}+\mathrm{Cr}+\mathrm{Al})$ & 0.84 & 0.88 & 0.81 & 0.93 & 0.33 & 0.90 & 0.34 \\
\hline
\end{tabular}

\begin{tabular}{lrrrrrrr}
\hline $\begin{array}{l}\text { Olivine } \\
\text { Oxide (wt\%) }\end{array}$ & \multicolumn{1}{c}{$\begin{array}{c}\text { 1 } \\
\text { macro }\end{array}$} & \multicolumn{1}{c}{$\begin{array}{c}\text { macro } \\
\text { macro }\end{array}$} & $\begin{array}{c}\text { macro } \\
\text { macro }\end{array}$ & $\begin{array}{r}\text { P2A-1* } \\
\text { apha** }\end{array}$ & $\begin{array}{r}\text { P2A-2* } \\
\text { apha** }\end{array}$ \\
\hline $\mathrm{SiO}_{2}$ & 40.75 & 41.26 & 41.63 & 40.80 & 39.87 & 39.32 & 39.16 \\
$\mathrm{TiO}_{2}$ & 0.10 & 0.05 & 0.01 & 0.00 & 0.15 & 0.09 & 0.34 \\
$\mathrm{Al}_{2} \mathrm{O}_{3}$ & 0.03 & 0.03 & 0.03 & 0.01 & 2.21 & 4.98 & 1.84 \\
$\mathrm{Cr}_{2} \mathrm{O}_{3}$ & 0.04 & 0.04 & 0.07 & 0.00 & 0.12 & 0.31 & 0.26 \\
$\mathrm{FeO}$ & 10.81 & 10.34 & 8.26 & 8.60 & 5.19 & 4.68 & 7.55 \\
$\mathrm{MnO}$ & 0.16 & 0.18 & 0.11 & 0.14 & 0.15 & 0.05 & 0.06 \\
$\mathrm{MgO}$ & 47.07 & 47.03 & 48.57 & 48.88 & 38.23 & 35.31 & 36.39 \\
$\mathrm{CaO}$ & 0.18 & 0.23 & 0.08 & 0.13 & 0.43 & 0.42 & 0.33 \\
$\mathrm{Na}$ & 0.01 & 0.02 & 0.04 & 0.03 & 0.00 & 0.00 & 0.01 \\
$\mathrm{~K}_{2} \mathrm{O}$ & 0.00 & 0.00 & 0.00 & 0.00 & 0.05 & 0.05 & 0.00 \\
$\mathrm{P}_{2} \mathrm{O}_{5}$ & 0.00 & 0.00 & 0.00 & 0.00 & 0.02 & 0.01 & 0.02 \\
$\mathrm{ZnO}$ & 0.12 & 0.02 & 0.02 & 0.03 & 0.00 & 0.00 & 0.00 \\
$\mathrm{Total}$ & 99.25 & 99.14 & 98.80 & 98.54 & 86.42 & 85.22 & 85.96 \\
$\mathrm{Fo}$ & 88.44 & 88.55 & 91.19 & 90.89 & 92.73 & 93.01 & 89.50 \\
$\mathrm{Fa}$ & 11.39 & 10.96 & 8.70 & 8.97 & 7.06 & 6.92 & 10.42 \\
\hline
\end{tabular}

Note: macro, macrocrystic; apha, aphanitic.

* Data from Chalapathi Rao and Srivastava (2009).

** Serpentinised olivines. 

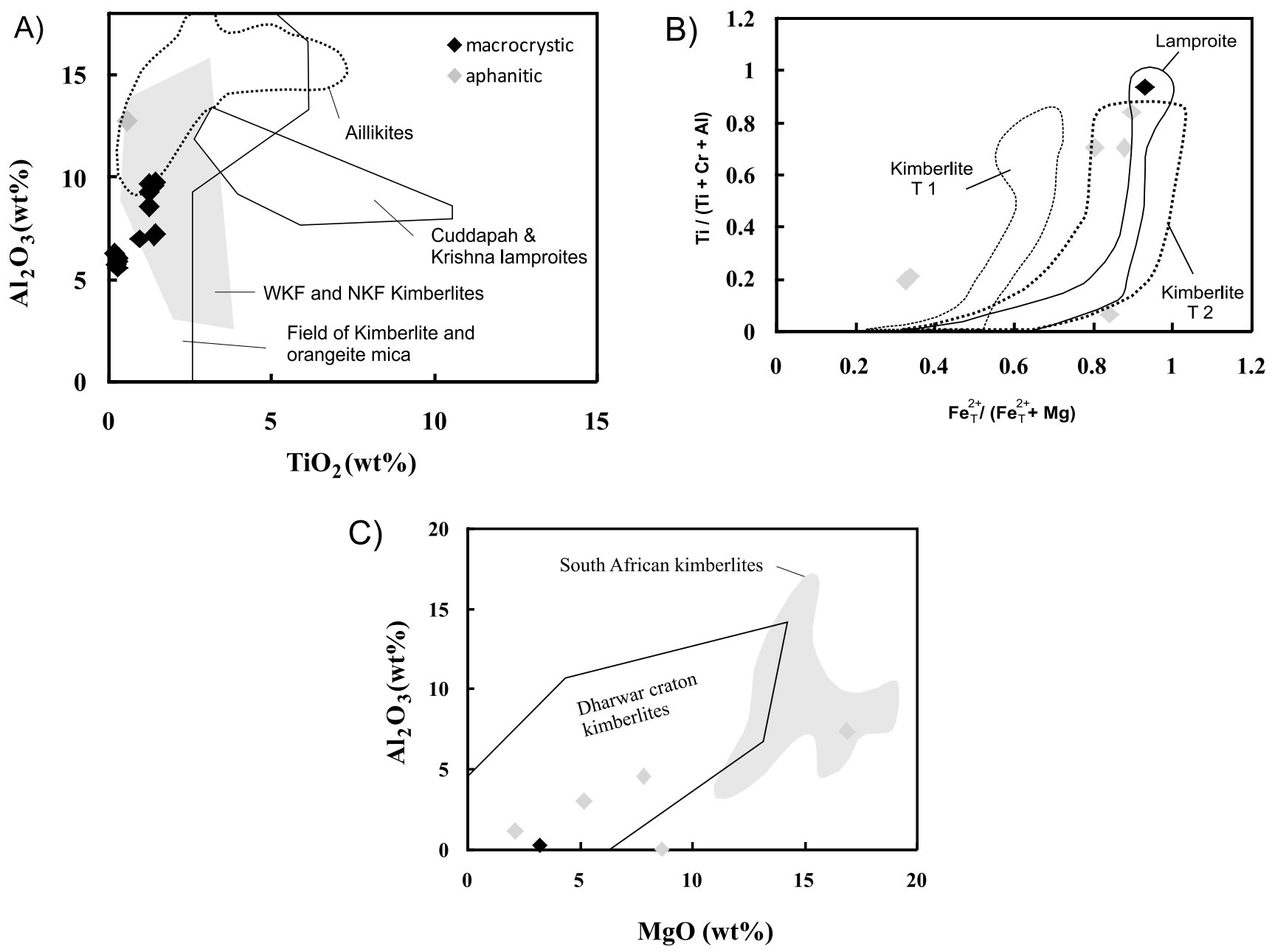

Fig. 3. (a) $\mathrm{TiO}_{2}$ vs. $\mathrm{Al}_{2} \mathrm{O}_{3}(w t \%)$ variation plot for phlogopite of Pipe 2 kimberlite. Data for WKF and NKF kimberlites are from Chalapathi Rao et al. (2004); Cuddapah and Krishna lamproites, Eastern Dharwar craton, are from Chalapathi Rao et al. (2010). Field of kimberlite is taken from Dawson and Smith (1977) and aillikite is from Tappe et al. (2006). (b) $\mathrm{Fe}^{2+} /\left(\mathrm{Fe}^{2++} \mathrm{Mg}^{2+}\right)$ vs. Ti/(Ti+Cr+Al) (mol fraction) for groundmass spinel from Pipe 2 kimberlite. Kimberlite Trend 1 and 2 are from Mitchell (1986, 1995a). Lamproite field is from Mitchell and Bergman (1991). (c) $\mathrm{MgO}$ (wt\%) vs. $\mathrm{Al}_{2} \mathrm{O}_{3}$ (wt\%) of spinels of this study. Data for aphanitic variety of Pipe 2 kimberlite from Chalapathi Rao and Srivastava (2009) also plotted for comparison.

ally two trends are shown by groundmass spinels from kimberlites: magmatic trend 1 or the magnesian ulvospinel trend; and magmatic trend 2 or the titanomagnetite trend (Mitchell, 1995a). Magmatic trend 1 is recognized as the characteristic spinel compositional trend of archetypal kimberlites (Mitchell, 1986). Magmatic trend 2 is uncommon in archetypal kimberlites while typical for orangeites and this trend is characterized by rapid $\mathrm{MgO}$ depletion (Mitchell, 1995a). However, spinels of very similar composition to trend 2 are also found in some lamproites (Mitchell and Bergman, 1991) and in certain ultramafic lamprophyres such as aillikites (Tappe et al., 2005). Interestingly aphanitic samples show affinity towards magmatic trend 2 indicating rapid depletion of $\mathrm{MgO}$ in their source magma (Fig. 3b). However, all the samples with the exception of two samples with high $\mathrm{Cr}$ spinels $\left(\mathrm{Cr}_{2} \mathrm{O}_{3}\right.$ : 27.4-29.9 wt\%; data from Chalapathi Rao and Srivastava, 2009) show strong affinity to kimberlite trend 2 spinels than the lamproite trend (Fig. 4a) and mostly confined to the field of Dharwar craton kimberlites (Fig. 3c).

\section{Olivine}

In macrocrystic variety both macrocrysts as well as microphenocrysts of olivines are present whereas in aphanitic variety macrocrysts are rare and the intrusion is abundant in altered microphenocrysts of olivine. Olivines have compositions from $\mathrm{Fo}_{88}$ to $\mathrm{Fo}_{93}$. Olivines in aphanitic variety are pseudomorphed to serpentine while in macrocrystic variety they are comparatively fresh and macrocrysts occur as broken fragments in the 

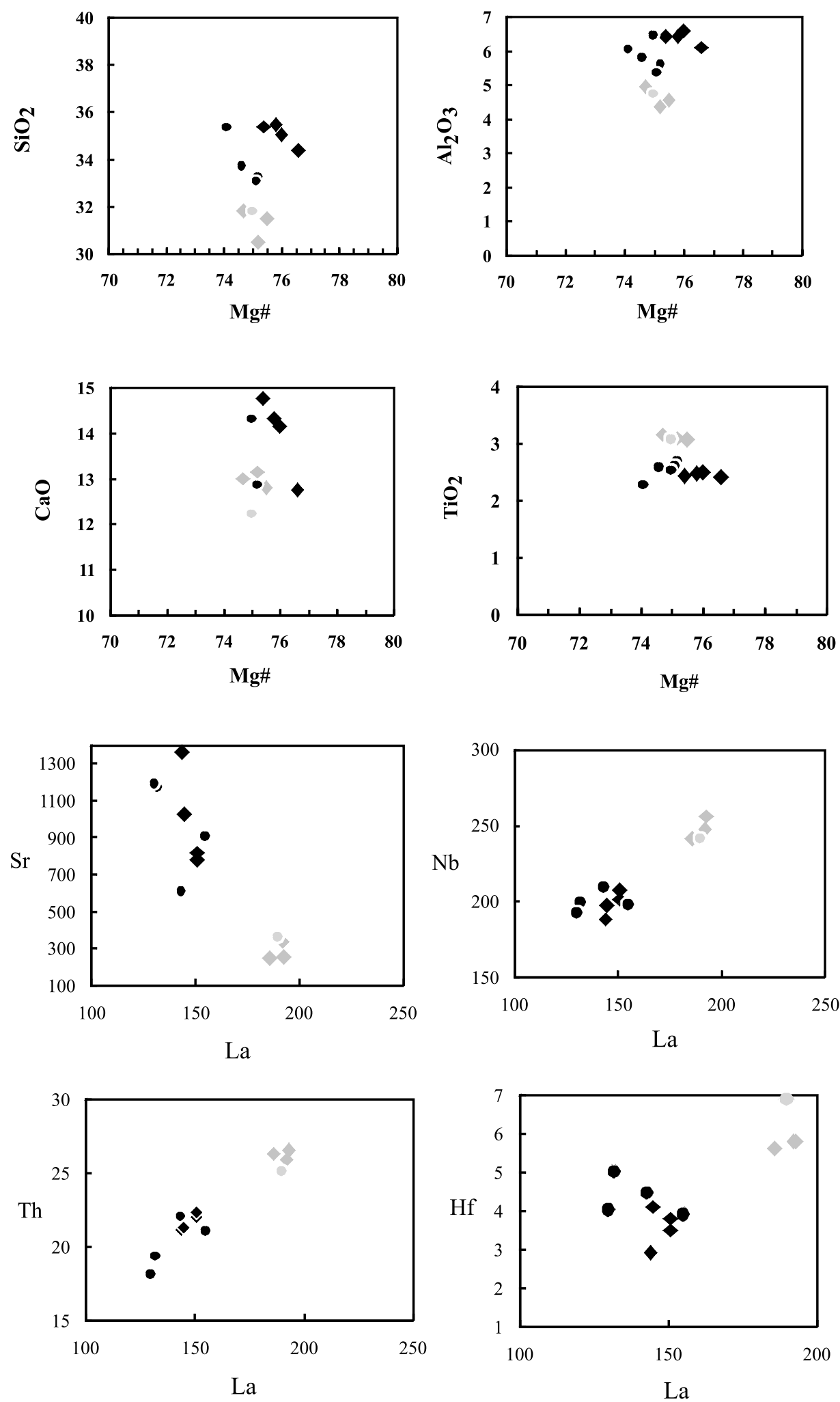

Fig. 4. Variation diagrams showing Mg\# versus selected major oxides and La versus selected trace elements in Pipe 2 kimberlite. Symbols are black diamond and black circles for macrocrystic, gray diamonds and gray circles for aphanitic. Black and gray circles are data from Chalapathi Rao et al. (2004) and Chalapathi Rao and Srivastava (2009) also plotted for comparison. 


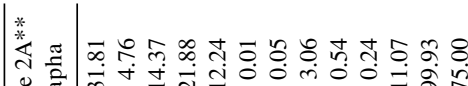

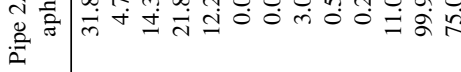

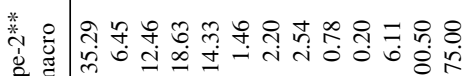

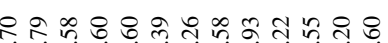

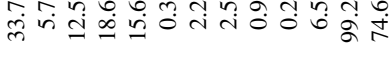

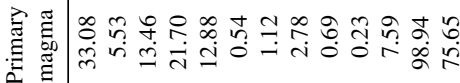

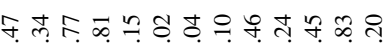

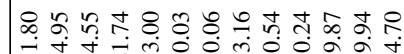

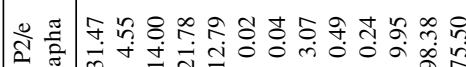

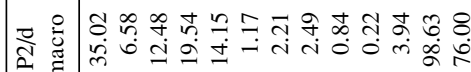

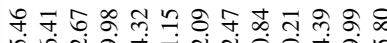

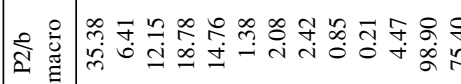

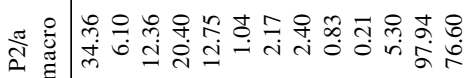

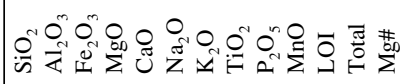

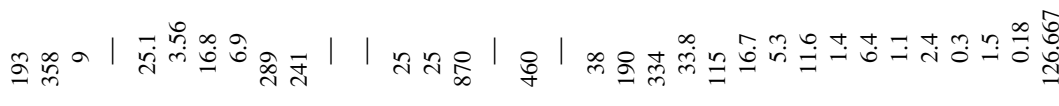

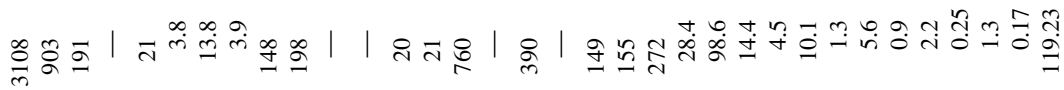

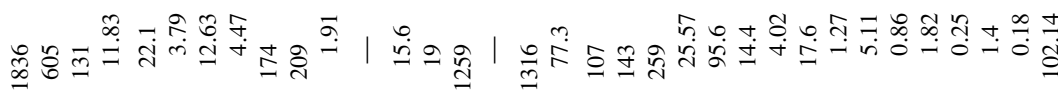

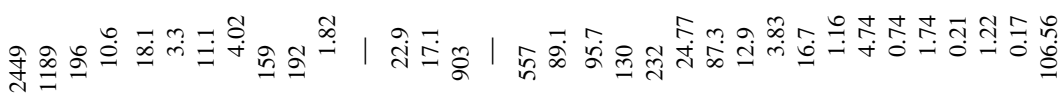

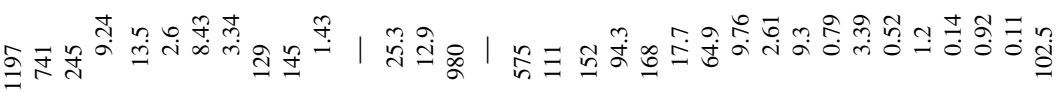

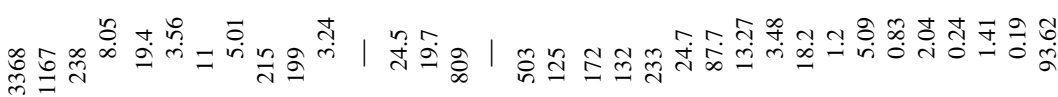

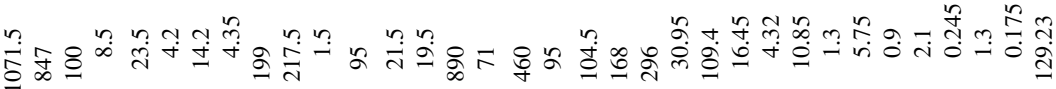

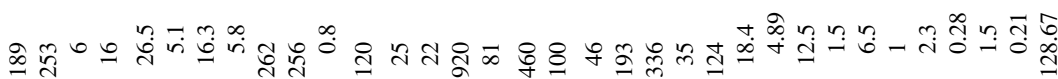

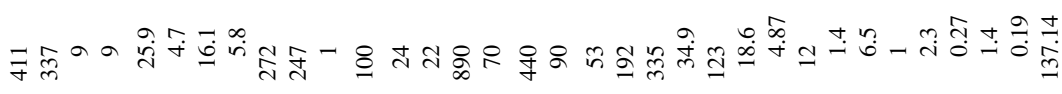

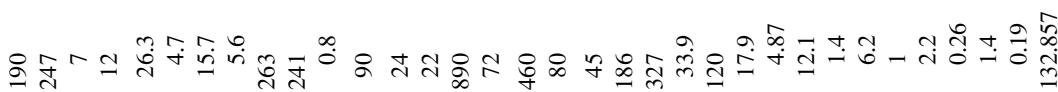

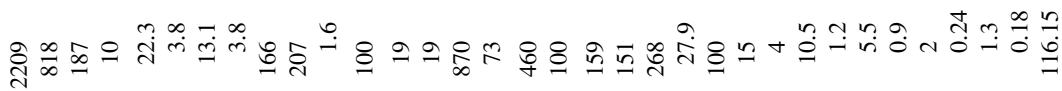

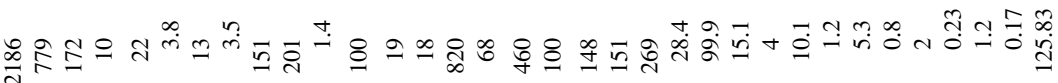

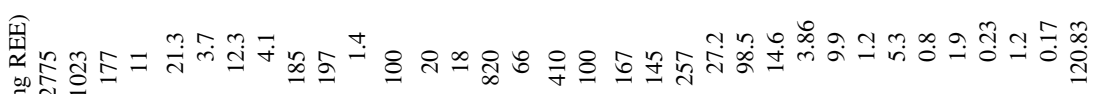
要

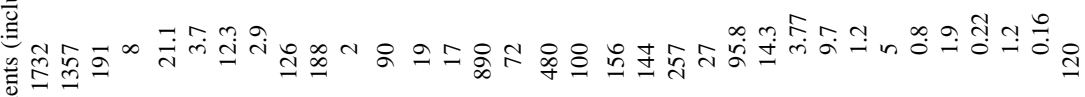
这

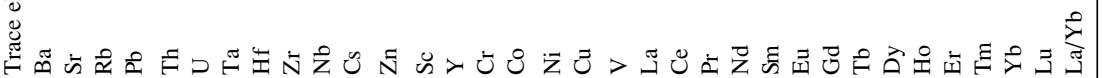


A)

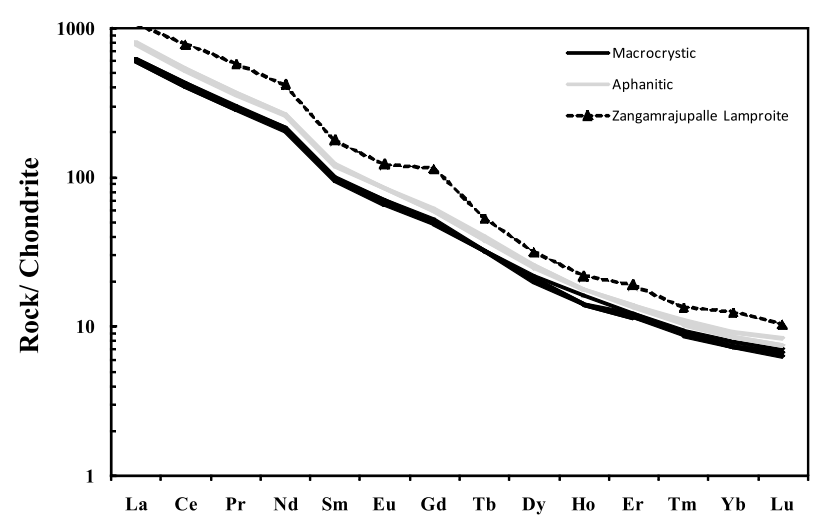

B)

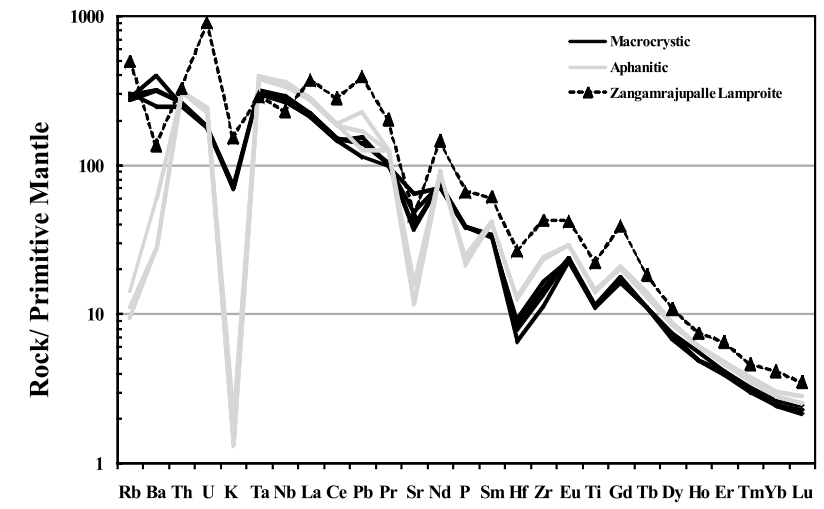

Fig. 5. (a) Chondrite normalized (values from Evensen et al., 1978) REE abundances for kimberlite samples of this study. (b) Primitive mantle normalized trace element patterns for kimberlite samples under study. Normalizing values are from Sun and McDonough (1989). Data for Zangamrajupalle lamproite is from Chalapathi Rao et al. (2004). Only kimberlite samples under study are plotted to aid clarity.

groundmass. High magnesian composition of Pipe 2 kimberlite reflects that of its source.

\section{GEOCHEMISTRY}

\section{Major element geochemistry}

New major and trace element data for the Pipe 2 kimberlites are presented in Table 2. Pipe 2 kimberlite shows low $\mathrm{SiO}_{2}$ content (30.47-35.46 wt\%) displaying its mafic, ultramafic nature. $\mathrm{SiO}_{2}$ content in macrocrystic variety is comparatively higher (34-35 wt $\%$ ) than the aphanitic variety (30-31 wt\%). Distinction based on $\mathrm{MgO}$ content is obvious in macrocrystic and aphanitic varieties. Macrocrystic Pipe 2 west shows lower $\mathrm{MgO}$ content (18.78-20.4 wt\%) whereas aphanitic Pipe 2 east shows slightly higher $\mathrm{MgO}$ ( 21 wt\%). However $\mathrm{Mg \#} \mathrm{(Mg/}$
$\mathrm{Mg}+\mathrm{Fe}$ ) is not consistent with the $\mathrm{MgO}$ content and val-

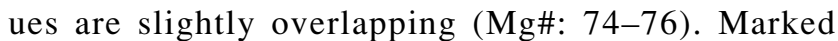
geochemical difference is observed between macrocrystic and aphanitic varieties. $\mathrm{Fe}_{2} \mathrm{O}_{3(\mathrm{~T})}$ concentrations in all the samples vary from 12.15 to $14.55 \mathrm{wt} \%$ with higher values in aphanitic. Macrocrystic samples shows higher concentrations of $\mathrm{Al}_{2} \mathrm{O}_{3}(6.1-6.5 \mathrm{wt} \%), \mathrm{CaO}$ (12.75-14.76 wt $\%), \mathrm{Na}_{2} \mathrm{O}(1.04-1.38 \mathrm{wt} \%), \mathrm{K}_{2} \mathrm{O}(2.08-2.21 \mathrm{wt} \%)$ and $\mathrm{P}_{2} \mathrm{O}_{5}(0.83-0.84 \mathrm{wt} \%)$ whereas aphanitic samples shows lower $\mathrm{Al}_{2} \mathrm{O}_{3}$ (4.34 to $\left.4.95 \mathrm{wt} \%\right), \mathrm{CaO}$ (12.79 to 13.15 wt $\%), \mathrm{Na}_{2} \mathrm{O}(0.02-0.03 \mathrm{wt} \%), \mathrm{K}_{2} \mathrm{O}(0.04$ to $0.06 \mathrm{wt} \%)$ and $\mathrm{P}_{2} \mathrm{O}_{5}(0.46-0.54 \mathrm{wt} \%)$ concentrations. $\mathrm{K}_{2} \mathrm{O}$ content of aphanitic variety is very low which may be due to very low abundances of modal phlogopite while that of macrocrystic is high reflecting their higher modal phlogopite. The $\mathrm{TiO}_{2}$ content of macrocrystic samples is however low $(\sim 2.4 \mathrm{wt} \%)$ while aphanitic samples are showing high concentrations of $\mathrm{TiO}_{2}$ varying from 3 to $3.16 \mathrm{wt} \%$. When plotted against $\mathrm{Mg} \#, \mathrm{SiO}_{2}$ and $\mathrm{Al}_{2} \mathrm{O}_{3}$ show broad positive correlation whereas $\mathrm{CaO}$ and $\mathrm{TiO}_{2}$ show negative correlation (Fig. 4).

\section{Trace element geochemistry}

The transition metals $\mathrm{Ni}$ (410 to $480 \mathrm{ppm}$ ) and $\mathrm{Cr}$ (820 to $920 \mathrm{ppm}$ ) in all the samples are higher and shows restricted range in abundance. The Pipe 2 kimberlite shows considerably lower values of $\mathrm{Ni}$ and $\mathrm{Cr}$ than other EDC kimberlites (Ni: 930-1079 ppm and Cr: 943-965 ppm; data source: Chalapathi Rao and Srivastava, 2009). Trace and rare earth elements also show considerable difference in their abundances in macrocrystic and aphanitic variety. High field strength elements (HFSE) which are immobile during hydrothermal alteration are reasonably high in abundances in aphanitic (La: 186-193 ppm, Th: 25-26 ppm, Nb: 241-256 ppm, Total REE $=714-737)$ whereas large ion lithophile element concentrations like $\mathrm{Rb}$ ( 7 to $9 \mathrm{ppm}$ ) and $\mathrm{Ba}$ (189 to 411) are comparatively lower. However macrocrystic samples shows highest content of $\mathrm{Rb}$ (172-191 ppm) and $\mathrm{Ba}(1732-2775 \mathrm{ppm})$. In the bivariate plots HFSE elements (such as $\mathrm{Nb}$, Th and $\mathrm{Hf}$ ) shows broad positive correlation with La while LILE elements (like $\mathrm{Rb}$ and $\mathrm{Sr}$ ) shows broad negative correlation (Fig. 4).

All the samples of this study shows similar fractionated $(\mathrm{La} / \mathrm{Yb}=116-137)$ chondrite normalized REE pattern with higher La abundances in the range 600 800 times chondrites and low HREE abundances of 6-8 $\times$ chondrite (Fig. 5a). Aphanitic particularly shows higher abundances in REE than the macrocrystic. The steep slope of the REE patterns coupled with low HREE suggests derivation from the garnet-stability field (e.g., Gaffney et al., 2007).

Primitive mantle normalized trace element pattern also shows enrichment of aphanitic samples over the 
macrocrystic except for elements $\mathrm{Rb}, \mathrm{Ba}, \mathrm{K}, \mathrm{Sr}$ and P. All the samples show parallel patterns with depletions in $\mathrm{K}$, $\mathrm{Sr}$, Hf and Ti. Aphanitic samples show additional depletions at $\mathrm{Rb}, \mathrm{Ba}$ and $\mathrm{P}$ (Fig. 5b). Three samples from macrocrystic exhibit small positive Ba anomaly. Negative troughs at $\mathrm{Rb}, \mathrm{Ba}, \mathrm{K}, \mathrm{Sr}$ and $\mathrm{P}$ in aphanitic samples are more pronounced than the macrocrystic. These negative anomalies are known from Group I kimberlites of South Africa (e.g., Le Roex et al., 2003; Harris et al., 2004) and India (Chalapathi Rao and Srivastava, 2009) and are considered to be characteristic feature of kimberlites. Trace element pattern also shows distinction between Pipe 2 samples and lamproite from Zangamrajupalle from Cuddapah basin (Chalapathi Rao et al., 2004) which is more enriched in trace elements (Figs. 5a and b).

\section{Petrogenesis}

Kimberlites generally entrain numerous xenoliths, large portion of which is crustal (e.g., Dawson, 1980; Mitchell, 1995a). Therefore before drawing any conclusions on genesis and source region of Pipe 2 kimberlite, it is important to evaluate the extent of crustal contamination and alteration.

\section{Crustal contamination and deuteric alteration}

All xenoliths and visible altered or veined material was removed before powdering and analysis to minimize the effects of alteration and secondary contamination. Still it is likely, that some assimilation might have occurred and could not be avoided due to low-melting temperature of crustal xenoliths. Clement's (1982) contamination index (C.I.) values $<1$ are considered uncontaminated, although Clement (1982) reported C.I. values up to 1.5 for crustally uncontaminated kimberlites. The aphanitic samples show C.I. values close to $\sim 1.5$, whereas macrocrystic samples have slightly higher C.I. values range from 1.82. Kjarsgaard et al. (2009) evaluated the contamination index (C.I.) and concluded need of its utilization in conjunction with other geochemical screens. Fesq et al. (1975) shown that $\mathrm{Si} / \mathrm{Mg}$ values of $>1.2$ implies crustal contamination. The $\mathrm{Si} / \mathrm{Mg}$ values for aphanitic samples are within range (i.e., $<1.2$ ) while macrocrystic samples shows values close to $\sim 1.2$ signifying the crustal contamination to be not a significant factor. Although C.I. values, $\mathrm{Al}_{2} \mathrm{O}_{3}$ and $\mathrm{Na}_{2} \mathrm{O}$ contents are slightly higher in macrocrystic, evidence against crustal contamination comes from lower values of $\mathrm{SiO}_{2}(34-35 \mathrm{wt} \%)$ and higher $\mathrm{MgO}(18-20 \mathrm{wt} \%)$ content. Petrographic study reveals that the macrocrystic variety is fairly fresh whereas extensive serpentinization is observed in aphanitic variety. Widespread serpentinization could be due to water-rich character of high temperature fluids (hydrothermal flu- ids) which results in pervasive deuteric alteration (hydrothermal alteration). This hydrothermal fluid can alter the initial concentrations of fluid mobile LIL elements (e.g., $\mathrm{Rb}, \mathrm{Ba}, \mathrm{Sr}$ and $\mathrm{K}$ ) whereas concentrations of high field strength elements will be remain robust. Figure 4 shows immobile incompatible element La behaves coherently with other HFS and LIL elements which contradicts the pronounced effects of hydrothermal alteration. On multielement plot (Fig. 5b) Rb, Ba, $\mathrm{K}$ and $\mathrm{Sr}$ shows negative anomalies wherein they are more pronounced in aphanitic samples as compared to macrocrystic ones. The reasons for these anomalies are dealt separately in a later section. The more scatter in abundance of these fluid mobile elements, however, indicates possible effects of deuteric alteration in aphanitic variety. Since the presence of olivine crystallization, the whole rock $\mathrm{MgO}$ should be significantly depleted in aphanitic variety than the macrocrystic samples. However fine grained aphanitic samples shows more abundances of $\mathrm{MgO}(\sim 21 \mathrm{wt} \%)$ than macrocrystic (18-20 wt\%). Under hydrothermal alteration in fine grained rocks like basalts $\mathrm{Mg}$ element shows mobility and increase in abundances (Mottl, 1983). Interestingly, Sparks et al. (2009) shown that the composition of kimberlite magma during eruption undergoes large volume changes in chemically open system due to strong alteration, notably by serpentinisation, which leads to increase in $\mathrm{SiO}_{2}$ and $\mathrm{MgO}$ in bulk rock chemistry. Therefore the mobility and enrichment in $\mathrm{MgO}$ in fine grained aphanitic variety can be attributed to effects of alteration and serpentinisation although in this case the $\mathrm{Mg}$ numbers remains more or less robust.

\section{Close to primary magma composition}

To propose the close to primary kimberlite magma compositions one has to take into consideration that the magmas should be least affected by alteration, crustal contamination and fractional crystallization. In addition, high $\mathrm{Mg}$ numbers, high content of $\mathrm{Ni}$ and $\mathrm{Cr}$ also imply primitive nature of magmas. Owing to presence of both aphanitic and macrocrystic varieties in Pipe 2 kimberlite as well as in view of the mobility of $\mathrm{MgO}$ due to alteration and serpentinisation, the primary magma composition is taken as average of least $\mathrm{SiO}_{2}$ rich macrocrystic sample (P2-1) and most $\mathrm{SiO}_{2}$ rich aphanitic sample (P26). The average most closely represents the primary Pipe 2 kimberlite magma composition and contains $\sim 33 \mathrm{wt} \%$ $\mathrm{SiO}_{2}, \mathrm{Mg \#} \sim 75.6$ and $460 \mathrm{ppm} \mathrm{Ni} \mathrm{(Table} \mathrm{2).}$

\section{Fractional crystallization}

Only phenocryst poor or aphanitic rocks like Pipe 2 east kimberlite will give a true indication of the liquid path. On the other hand macrocrystic kimberlite does not represent a liquid composition and Le Roex et al. (2003) have shown that it represents a partial cumulate of man- 
tle derived minerals dominated by olivine. Harris et al. (2004) have shown that the compositions of the macrocrystic kimberlites reflect variable entrainment of mantle lherzolite and megacryst phases into primary kimberlite magma. Figure 6 shows strong positive correlation between $\mathrm{Mg \#}$ and $\mathrm{Ni}$. The $\mathrm{Ni}$ and $\mathrm{Mg \#}$ tend to be buffered during mantle melting processes by olivine and orthopyroxene due to which coherent correlation is not expected during variable degrees of partial melting (Harris et al., 2004). Therefore, compositional variation shown by aphanitic and macrocrystic samples is more consistent with crystal fractionation process and it is evident that up to $\sim 5 \%$ fractionation of olivine is responsible for the observed variation shown by aphanitic samples. Evidence for involvement of minor phlogopite as a fractionating phase is found in more pronounced negative $\mathrm{Rb}$ and $\mathrm{K}$ anomalies in aphanitic samples. But the role of hydrothermal fluid in scatter of this highly mobile element cannot be ruled out. Evidence against considerable amount of fractionation of phlogopite comes from relative low modal abundance of phlogopite in aphanitic samples. The Ti depletion is of almost same magnitude in aphanitic and macrocrystic variety and therefore precludes the possibility of involvement of ilmenite/perovskite fractionation. The compositions of macrocrystic kimberlite are inferred to reflect entrainment of mantle material such as garnet lherzolite (Le Roex et al., 2003; Harris et al., 2004). Such type of entrainment could lead to an increase in $\mathrm{Ni}, \mathrm{Cr}$ and $\mathrm{Mg \#}$ contents in macrocrystic variety. However, it is clear that addition of such mantle derived material will elevate the absolute REE instead of diluting the abundances and trends in Fig. 6 and REE abundances of macrocrystic kimberlite show that such entrainment of mantle material is negligible in bringing out the observed differences in macrocrystic variety. Therefore it is clear that aphanitic and macrocrystic varieties of Pipe 2 kimberlite have experienced different evolutionary histories.

\section{Partial melting}

Experimental data reveals that Group I and Group II kimberlite like magmas can be produced by very low degrees of partial melting of carbonated garnet harzburgite or lherzolite (Canil and Scarfe, 1990; Dalton and Presnall, 1998; Ulmer and Sweeney, 2002). Most models of kimberlite petrogenesis also focus on their formation by a small amount of partial melting of upper mantle peridotite. Trace elements can be used to model this process if a reasonable mineralogy of the source, trace element content of the source and percent melting can be assumed and if it is known how the trace element partition between the source and melt. Le Roex et al. (2003) and Becker and Le Roex, (2006) in their modeling for South African kimberlites employed partition coefficients

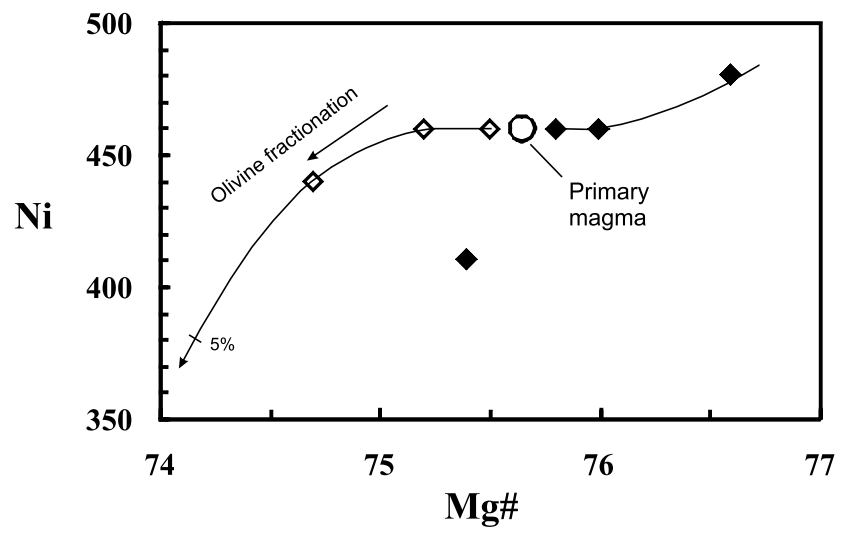

Fig. 6. Ni vs. Mg number for kimberlite samples under study. Olivine fractionation curve calculated assuming equilibrium crystallization. $D^{N i}=124 / \mathrm{MgO}-0.9$ (Hart and Davis, 1978). Circle shows composition of inferred primary magma composition. Only kimberlite samples under study are plotted to aid clarity.

for volatile poor basaltic system given by Spath et al. (2001) which are at the low end of all measured ranges for these mineral melt pairs. Recently in an alternate approach Tappe et al. $(2011,2013)$ utilized new sets of "bulk" peridotite/melt partition coefficients (Brey et al., 2008; Dasgupta et al., 2009) to calculate trace element patterns for partial melts of carbonated peridotite between 6 and $10 \mathrm{GPa}$. This alternate modeling shows that strong metasomatic enrichment (e.g., Le Roex et al., 2003) of the source region is not a requirement as long as the system is $\mathrm{CO}_{2}$ saturated. We however, adopted trace element modeling approach of Le Roex et al. (2003) to estimate the source composition of Pipe 2 primary kimberlite magma in an effort to test whether the Southern African model is applicable for the Indian samples.

Figure 7a shows the chondrite normalized REE abundances of the inferred primary magma of Pipe 2 . Here by semi-quantitative forward modelling we have estimated the source composition of close to primary kimberlite magma of Pipe 2 for very small (1\%) degree of partial melting. The calculated source composition is enriched in LREE ( $11 \times$ chondrite $)$ and HREE abundances almost equal to chondrite. It is notable that the calculated source composition falls within the field of garnet lherzolites from Kaapvaal craton (Gregoire et al., 2003). Changes in the degree of partial melting do not change the HREE content of calculated magma composition but leads to a range of LREE abundances. Therefore, the sub-parallel chondrite normalized REE patterns shown by the aphanitic kimberlite samples do not represent a suite of primary magmas derived by different degrees of melting but are consistent with the fractional crystallization trend. The source composition is calculated at $1 \%$ partial melt- 

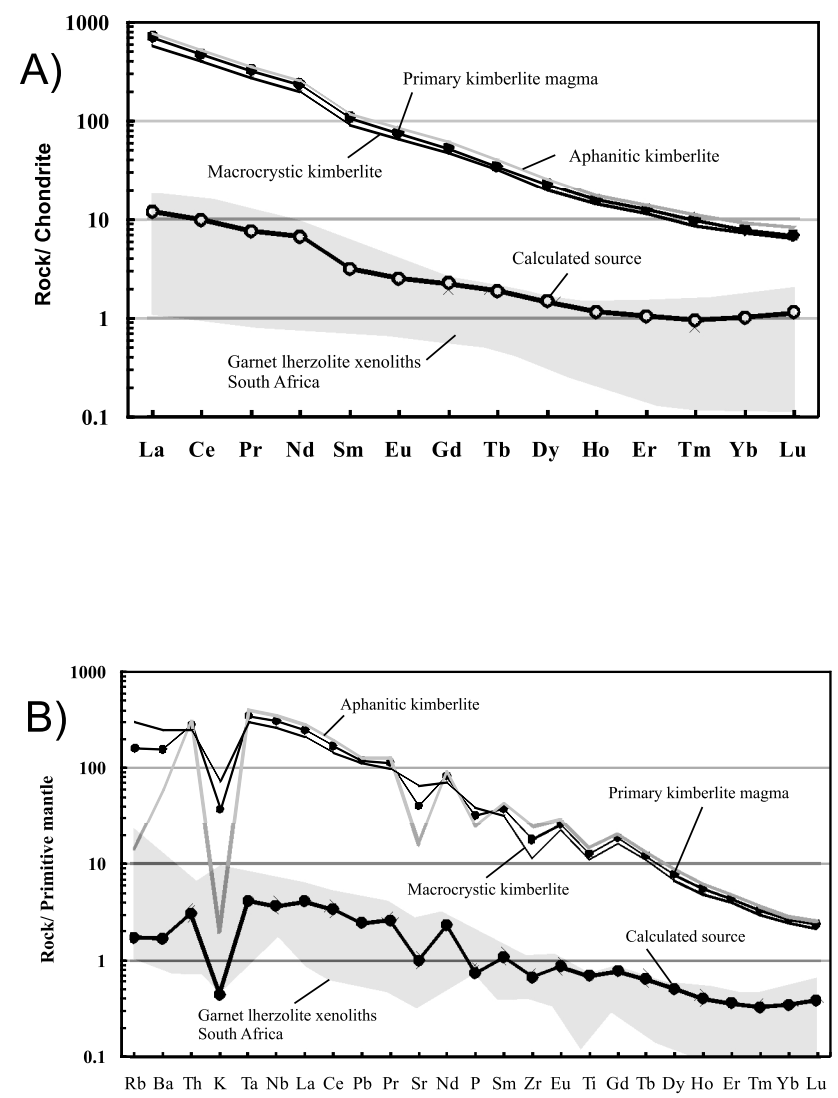

Fig. 7. (a) Chondrite normalized rare earth element and (b) primitive mantle normalized incompatible element abundances in the calculated mantle source regions determined by semi quantitative forward modeling from close-to-primary kimberlite magmas assuming $F=1 \%$ and residual modal mineralogy is ol:opx:cpx:gt $=0.63: 0.23: 0.12: 0.02$ reported by Harris et al. (2004). Partition coefficients from Spath et al. (2001). Normalizing values are from Sun and McDonough (1989). The field of Kaapvaal craton lherzolite is from Gregoire et al. (2003) plotted for comparison.

ing and with $2 \%$ residual garnet. The HREE are sensitive only to the amount of residual garnet and therefore any change or increase in the percentage of residual garnet will increase the HREE abundances (reflecting the high HREE partition coefficients for garnet) and elevate the HREE of calculated source to be greater than the chondrite value and out of garnet lherzolite field. Therefore, the $1 \%$ degree of melting is model dependant and also consistent with experimental evidences (e.g., Dalton and Presnall, 1998).

Primitive mantle normalized trace element diagram shows marked negative anomalies in $\mathrm{K}, \mathrm{Sr}, \mathrm{P}$, Ti and $\mathrm{Hf}$ (Fig. 5b). Negative anomalies are present in both the macrocrystic and aphanitic samples, wherein the aphanitic samples shows more pronounced negative anomalies at $\mathrm{Rb}, \mathrm{K}$ and $\mathrm{Sr}$. Presence of large $\mathrm{Rb}$ and $\mathrm{K}$ anomalies only in aphanitic samples reflects the combined role of very less amount of phlogopite fractionation and also the deuteric alteration in this fine grained variety.

Negative $\mathrm{Ti}$ and $\mathrm{Nb}$ anomalies always cannot be directly ascribed to the convergent margin setting; they may also reflect crustal contamination (Pearce and Peate, 1995; Polat et al., 2009). Furthermore, $\mathrm{Nb}$ and Ti depletion have also been explained in terms of the fractionation of $\mathrm{Fe}-$ Ti phases with high melt-mineral partition coefficients during fractionation processes (Foley et al., 2000; Hoffmann et al., 2012; Klemme et al., 2002). A positive correlation between the $\mathrm{Nb}$ and $\mathrm{Ti}$ would imply the fractionation of $\mathrm{Fe}-\mathrm{Ti}$ phases; however, the moderately negative correlation between $\mathrm{Ti}$ anomalies and $\mathrm{Nb}$ (Fig. $8 \mathrm{a}$ ) and absence of supporting $\mathrm{Nb}$ and $\mathrm{Ta}$ anomalies suggests that ilmenite or perovskite fractionation was insignificant in causing the Ti depletions, cannot be ascribed to convergent margin setting and is characteristic of source magma.

REE and HFSE behave coherently during partial melting of mantle and at the early stages of subsequent fractional crystallization which results into smooth trace element pattern. Any decoupling caused by some processes will result in a positive or negative HFSE anomaly. The subduction-related lavas (or subducted pelagic sediments) mainly exhibit the Hf and other HFSE anomalies (Pearce et al., 1999). In Fig. 8b, the $\mathrm{Gd} / \mathrm{Yb}>1$ implies downward slope of HREE and negative Hf anomaly correlates positively with HREE slope. This implies that Hf potentially controls by the crystal fractionation or subduction related process or is an inherent character of source magma. On primitive mantle trace element pattern $\mathrm{Hf}$ is the only HFSE which shows negative anomaly which negates the possible role of subduction. Negative Hf anomalies are constant and of same magnitude for both macrocrystic and aphanitic varieties, arguing against the cause being related to some crystal fractionation process. Therefore, the coherent relation of HREE with Hf anomaly is suggestive of primary kimberlite composition. Moreover recent results from kimberlite trace element modeling also support our conclusion that the Hf anomaly is source inherited (Tappe et al., 2011, 2013).

Negative Sr anomaly is also shown by both the macrocrystic and aphanitic samples and is more pronounced in aphanitic variety. Aphanitic samples are subjected to pronounced deuteric alteration which can also give rise to more scatter in large ion lithophile elements like $\mathrm{Sr}$. Negative anomaly in $\mathrm{Sr}$ is also a characteristic of garnet lherzolite source (Gregoire et al., 2003). Therefore, it is possible to impart the same in resultant primary kimberlite composition and is an intrinsic character of kimberlite source. However, Sr depletion can be accounted by the presence of clinopyroxene (e.g., Smith $e t$ al., 1985) or calcite (Keshav et al., 2005) in the source 
(A)

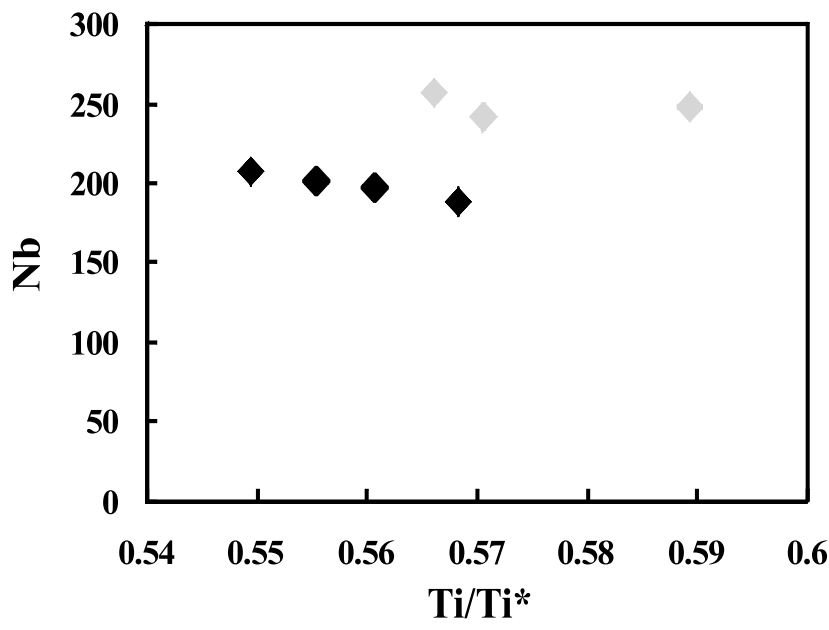

(C)

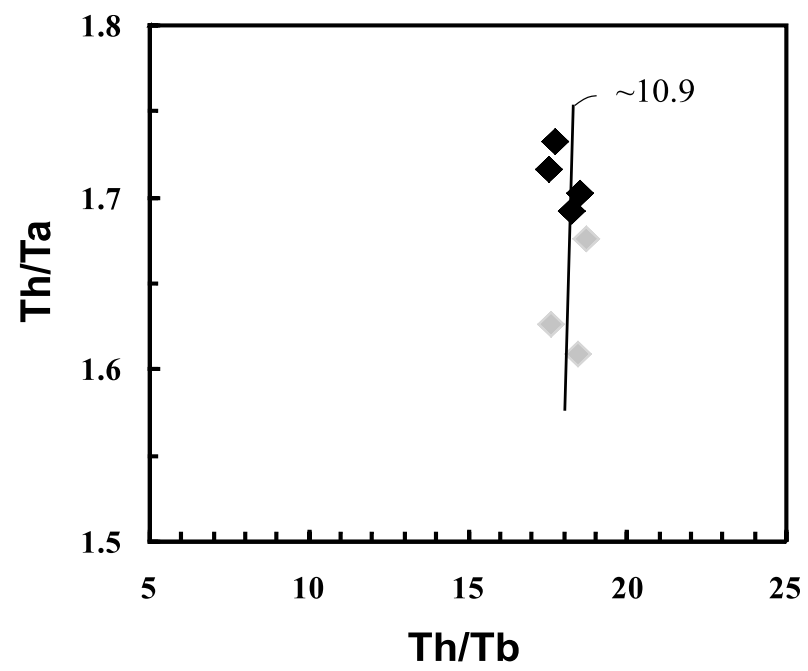

(B)

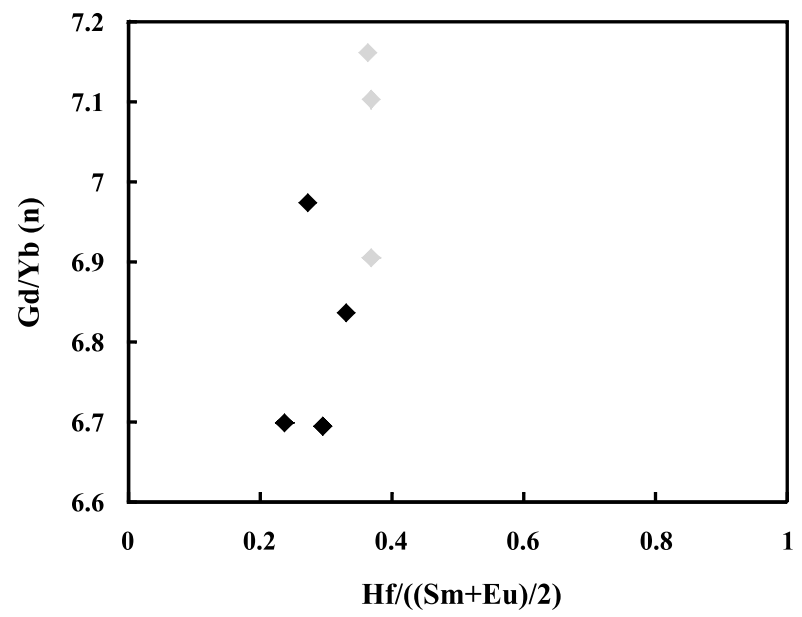

(D)

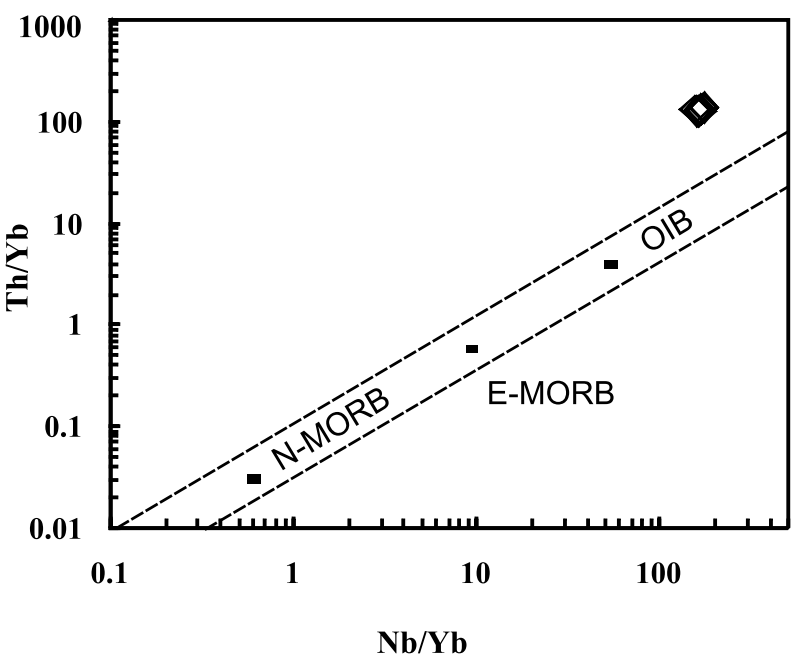

Fig. 8. (a) Plot of Ti/Ti*vs. Nb (ppm); (b) plot of Hf anomaly vs. $(G d / Y b)_{n}(c)$ variation of Th/Tb vs. Th/Ta; and (d) Nb/Yb vs. Th/ Yb diagram (Pearce, 2008; Pearce and Peate, 1995) for kimberlite samples under study.

region or even by an initial depletion due to melt extraction (e.g., Chalapathi Rao et al., 2004). Depletion at $\mathrm{P}$ indicates a residual phosphate bearing phase such as apatite or presence of a complex $\mathrm{K}-\mathrm{Ba}-\mathrm{P}$ rich metasomatic mineral phase (Mitchell, 1995b).

\section{DISCUSSION}

Recently, based on mineralogical studies Pipe 2 west was speculated to be an unusual lamproite like intrusion and not considered to be a bona fide kimberlite (Kaur and Mitchell, 2013; see also Reddy, 1987). Pipe 2 kimberlite have initial ${ }^{87} \mathrm{Sr} /{ }^{86} \mathrm{Sr}$ ratio of 0.7021 and ${ }^{143} \mathrm{Nd} /$ ${ }^{144} \mathrm{Nd}$ ratio of 0.51133 (Chalapathi Rao et al., 2004). These correspond to $\varepsilon \mathrm{Nd}_{\mathrm{i}}$ value of +1.96 . Because isotopes do not fractionate during partial melting or fractional crystallization process, they should be the most useful indicators of source variations. The initial Nd isotopic signature for Pipe 2 kimberlite is higher than bulk earth and similar to Group I kimberlite source regions. In the bivariate plots ( $\mathrm{La} / \mathrm{Nb}$ versus $\mathrm{Ba} / \mathrm{Nb}$ and $\mathrm{Th} / \mathrm{Nb}$ versus $\mathrm{Ce} / \mathrm{Pb}$ ) involving highly mobile as well as least mobile incompatible elements during hydrothermal alteration, Pipe 2 kimberlite display marked geochemical affinities 
towards Group I kimberlite of Southern Africa (Figs. 9a and b) than the lamproites. Comparatively lower incompatible elements ratios of Pipe 2 kimberlite $(\mathrm{La} / \mathrm{Nb}:<0.78$; $\mathrm{Ce} / \mathrm{Pb}<37.22)$ are distinct from lamproites which are highly enriched in these elements.

However, despite their observed geochemical difference in aphanitic and macrocrystic samples ratio-ratio plot between $\mathrm{Th} / \mathrm{Tb}$ and $\mathrm{Th} / \mathrm{Ta}$ (Fig. 8c) shows that the overall trend showing ratio of $\sim 10.9$ indicates the same mantle source.

Fabric indicates (Fig. 2) the introduction of phlogopite vein into olivine macrocryst and frequently overgrows and therefore post dates the enclosing olivine. Late crystallizing hydrous minerals are generally considered as a product of modal mantle metasomatism (Kempton et al., 1988). Lloyd et al. (1991) reported phlogopite veins of similar nature in orthopyroxene free Group I mantle xenoliths. Petrographic observation in Pipe 2 kimberlite strongly indicates that veined phlogopite is also a late crystallizing phase and is partially resorbed by the kimberlite magma. Phlogopite veins enrichment in olivine macrocryst suite closely follows the infiltration of phlogopite and provides evidence for the introduction of $\mathrm{Al}, \mathrm{Ti}$ and $\mathrm{K}$ rich hydrous silicate melt into mantle xenolith giving rise to mantle modal metasomatism.

The modelling of trace elements shows that the melting of garnet lherzolite source for about $1 \%$ can produce the observed trace and REE pattern of close to primary kimberlite magma. The source of Pipe 2 close to primary kimberlite magma is enriched in LREE (La: $\sim 11 \times$ chondrite) and depleted in HREE (Lu: $1 \times$ chondrite, Fig. $7 \mathrm{a})$. This source is also enriched in the highly incompatible LILE and HFSE element relative to primitive mantle (Fig. 7b). The highly fractionated REE patterns of primary kimberlite magma coupled with low HREE suggests derivation from the garnet-stability field. The occurrence of diamond in the Pipe 2 kimberlite also indicates that the source region extended well into the diamond stability field at depths of $>150 \mathrm{~km}$. High concentrations of the compatible elements (e.g., $\mathrm{Ni}, \mathrm{Cr}$ ), high $\mathrm{Mg \#}$ and very low concentration of HREE also indicate a source that had experienced a previous depletion event (Tainton and McKenzie, 1994; Beard et al., 2000; Le Roex et al., 2003). Incompatible elements ratios shown by Pipe 2 kimberlite are more enriched than those of OIB (Fig. 8d) which is also a characteristic of Group I kimberlites of Kaapvaal craton (e.g., Le Roex et al., 2003) and many EDC kimberlites (e.g., Chalapathi Rao and Srivastava, 2009) and requires a trace element enriched (metasomatised) source region. Metasomatism (enrichment) of mantle source regions can be attributed to source enrichment processes like: 1) Subduction derived melts (e.g., Szabo et al., 1996; Murphy et al., 2002; Gaffney et al., 2007; Coe et al., 2008) and; 2) metasomatizing alkaline fluids
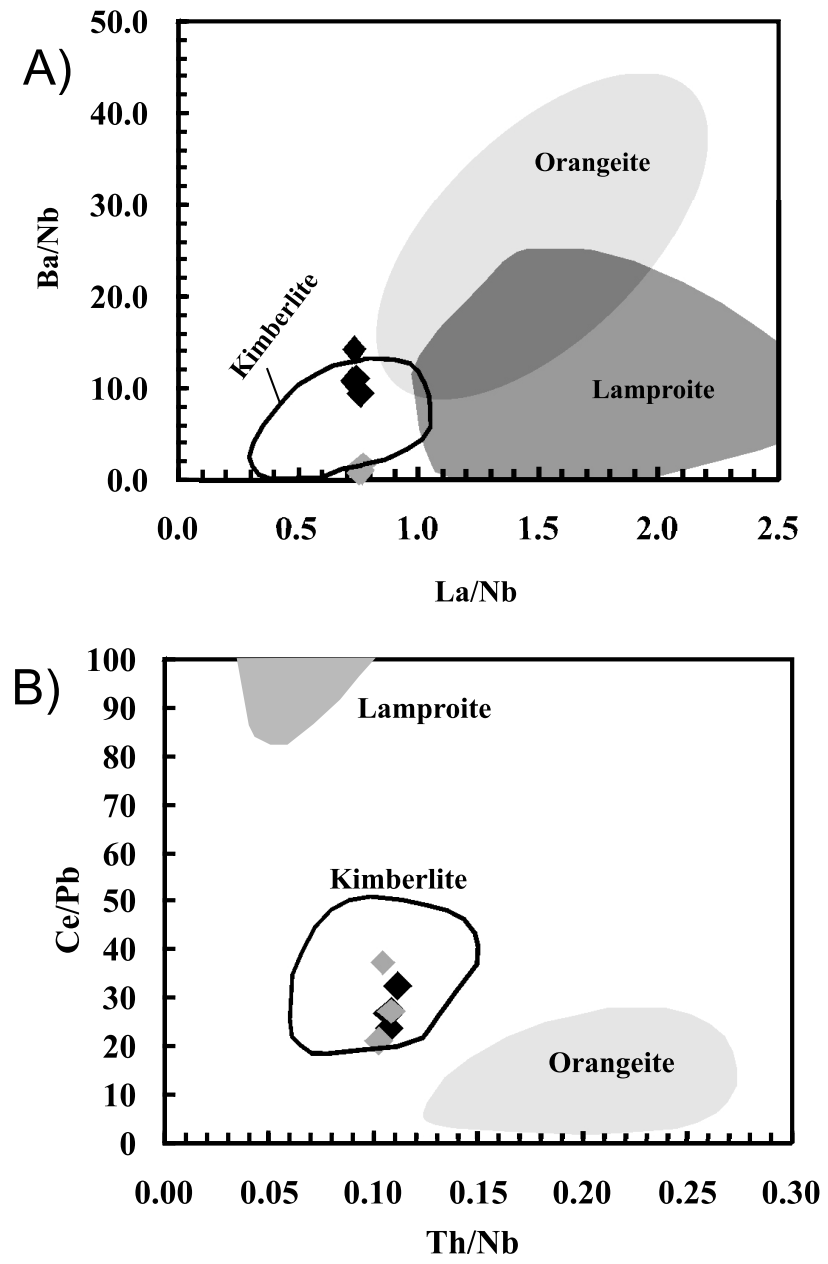

Fig. 9. Variation of (a) La/Nb vs. Ba/Nb and (b) Th/Nb vs. Cel $P b$ for kimberlite samples under study. Data for kimberlite from Le Roex et al. (2003); for orangeites from Coe (2004) and for lamproite from Chalapathi Rao et al. (2010).

or melts derived from the upwelling (asthenospheric) mantle, enriching the overlying sub-continental lithospheric mantle (SCLM) (e.g., Wyllie, 1987; McKenzie, 1989; Foley, 1992; Le Roex et al., 2003; Becker and Le Roex, 2006; Tappe et al., 2012). Furthermore, Tappe et al. (2013) recently demonstrated that geochemical affinity between kimberlites and OIB's can be generated by the melting of OIB type material such as seamount chains being transported into subduction zones enriching the overlying asthenosphere with OIB type melts which subsequently sampled by the kimberlites.

Our petrogenetic study reveals absence of any subduction related signatures in Pipe 2 kimberlite. Thus, a previously depleted as well as subsequently enriched mantle source is inferred in its genesis (see also Chalapathi Rao et al., 2004). A two stage model involving the source which has experienced initial depletion event and subse- 
quent enrichment by an upwelling mantle plume in generation of Group I kimberlites from Kimberley, South Africa is also suggested by Le Roex et al. (2003). We envisage here that OIB like fluids or melts derived from a convective asthenosphere initially metasomatized an already depleted sub-continental lithospheric mantle. Subsequent low degrees of partial melting $(\mathrm{F}=1 \%)$ of this metasomatized source (SCLM) gives rise to the primary kimberlite magma carrying OIB like incompatible trace element signatures.

\section{CONCLUSIONS}

Newly analyzed and available mineral chemical and whole rock geochemical data along with detailed petrography clearly point towards the kimberlitic nature of Pipe 2. Petrographic observations reveals infiltration of phlogopite veins in olivine macrocryst suite which gives evidence for the introduction of $\mathrm{Al}$, Ti and $\mathrm{K}$ rich hydrous silicate melt into source rock giving rise to mantle modal metasomatism and also for presence of veined mantle in source region. The aphanitic and macrocrystic varieties have distinct variation in their geochemistry where aphanitic samples seem to be more enriched in trace and rare earth elements.

The sub-parallel REE patterns shown by the aphanitic and macrocrystic samples do not represent a suite of primary magmas derived by different degrees of melting but consistent with the fractional crystallization trend. Up to $\sim 5 \%$ fractionation of olivine in primary magma appears to be responsible for observed variation shown by aphanitic samples. Therefore aphanitic and macrocrystic varieties of Pipe 2 kimberlite are inferred to be products of same mantle source (primary magma) but have experienced different evolutionary histories.

Simple batch melting model shows that average close to primary Pipe 2 kimberlite magma could have formed by very small degrees ( $1 \%$ ) of partial melting of a previously metasomatized garnet lherzolite source with $2 \%$ residual garnet. Marked negative anomalies in $\mathrm{K}, \mathrm{Sr}, \mathrm{P}$, $\mathrm{Ti}$ and $\mathrm{Hf}$ are present in both the macrocrystic and aphanitic samples. Depletions in $\mathrm{Ti}$ and $\mathrm{Hf}$ are not consistent with fractionation and do not confirm convergent margin setting moreover are characteristics of source magma. Therefore the melts derived from convecting mantle, rather than those linked with subduction related processes, are inferred to be agents of metasomatism in an already depleted sub-continental lithospheric mantle. Subsequent low degrees of partial melting $(\mathrm{F}=1 \%)$ of this metasomatized source (SCLM) is responsible for the generation of primary Pipe 2 kimberlite magma.

Acknowledgments - AD acknowledge financial support from Department of Science and Technology, New Delhi in the form of major research project grant under Fast Track Scheme for
Young Scientists (No. SR/FTP/ES-175/2010). NVCR thanks Head, Department of Geology, Banaras Hindu University, Varanasi, for support and encouragement. Journal reviewers Sebastian Tappe and Nitin Karmalkar, as well as editor Axel Hofmann provided constructive comments on this manuscript, for which we are sincerely grateful.

\section{REFERENCES}

Beard, A. D., Downes, H., Hegner, E., Sablukov, S. M., Vetrin, V. R. and Balogh, K. (1998) Mineralogy and geochemistry of Devonian ultramafic minor intrusions of the southern Kola peninsula, Russia: implications for the petrogenesis of kimberlites and melilitites. Contrib. Mineral. Petrol. 130, 288-303.

Beard, A. D., Downes, H., Hegner, E. and Sablukov, S. M. (2000) Geochemistry and mineralogy of kimberlites from the Arkhangelsk region, NW Russia: evidence for transitional kimberlite magma types. Lithos 51, 47-73.

Becker, M. and Le Roex, A. P. (2006) Geochemistry of South African On and Off-craton Group I and II kimberlites: petrogenesis and source region evaluation. J. Petrol. 47, 673-703.

Brey, G. P., Bulatov, V. K., Girnis, A. V. and Lahaye, Y. (2008) Experimental melting of carbonated peridotite at 6-10 GPa. J. Petrol. 49(4), 797-821.

Canil, D. and Scarfe, C. M. (1990) Phase relations in peridotite $\mathrm{CO}_{2}$ systems to $12 \mathrm{GPa}$ : implications for the origin of kimberlite and carbonate stability in the Earth's upper mantle. J. Geophy. Res. 95, 15805-15816.

Chalapathi Rao, N. V. and Srivastava, R. K. (2009) Petrology and geochemistry of diamondiferous Mesoproterozoic kimberlites from Wajrakarur kimberlite field, Eastern Dharwar craton, Southern India: genesis and constraints on mantle source regions. Contrib. Mineral. Petrol. 157, 245265.

Chalapathi Rao, N. V., Gibson, S. A., Pyle, D. M. and Dickin, A. P. (2004) Petrogenesis of Proterozoic lamproites and kimberlites from the Cuddapah Basin and Dharwar craton, southern India. J. Petrol. 45(5), 907-948.

Chalapathi Rao, N. V., Kamde, G., Kale, H. S. and Dongre, A. N. (2010) Petrogenesis of Mesoproterozoic lamproites from the Krishna valley, Eastern Dharwar craton, southern India. Precam. Res. 177, 103-130.

Chalapathi Rao, N. V., Creaser, R. A., Lehmann, B. and Panwar, B. K. (2013) Rs-Os isotopic study of Indian kimberlites and lamproites: Implications for mantle source regions and cratonic evolution. Chem. Geol. 353, 36-47.

Clement, C. R. (1982) A comparative geological study of some major kimberlite pipes in northern Cape and Orange Free State. Unpublished Ph.D. Thesis, Univ. of Cape Town, South Africa.

Coe, N. (2004) Petrogenesis of the Swartruggens and Star Group II kimberlite dyke swarms, South Africa. M.Sc. Thesis, Univ. of Cape Town, South Africa, 146 pp.

Coe, N., Le Roex, A., Gurney, J., Pearson, D. G. and Nowell, G. (2008) Petrogenesis of Swartruggens and Star Group II kimberlite dyke swarms, South Africa: constraints from whole rock geochemistry. Contrib. Mineral. Petrol. 156, 
627-652.

Dalton, J. A. and Presnall, D. C. (1998) The continuum of primary carbonatite-kimberlitic melt compositions in equilibrium lherzolite: data from the system $\mathrm{CaO}-\mathrm{MgO}-\mathrm{Al}_{2} \mathrm{O}_{3}-$ $\mathrm{SiO}_{2}-\mathrm{CaO}$ at $6 \mathrm{GPa}$. J. Petrol. 39, 1953-1964.

Dasgupta, R., Hirschmann, M. M., McDonough, W. F., Spiegelman, M. and Withers, A. C. (2009) Trace element partitioning between garnet lherzolite and carbonatite at 6.6 and $8.6 \mathrm{GPa}$ with applications to the geochemistry of the mantle and of mantle-derived melts. Chem. Geol. 262(12), 57-77.

Dawson, J. B. (1980) Kimberlites and Their Xenoliths. Springer Verlag, Berlin.

Dawson, J. B. and Smith, J. V. (1977) The MARID (micaamphibole-rutile-diopside) suite of xenoliths in kimberlite. Geochim. Cosmochim. Acta 41, 309-323.

Dhakate, M. V. and Nayak, S. S. (2002) Delineation of configuration and testing of diamondiferous nature of pipe-2 of wajrakarur, Anantapur district, Andhra Pradesh. Rec. Geol. Surv. India 135(5), 24-26.

Evensen, N. M., Hamilton, P. J. and O’Nions, R. K. (1978) Rare earth abundances in chondritic meteorites. Geochim. Cosmochim. Acta 42, 1199-1212.

Fesq, H. W., Kable, E. J. D. and Gurney, J. J. (1975) Aspects of the geochemistry of kimberlites from the Premier Mine and other South African occurrences, with particular reference to the rare earth elements. Phys. Chem. Earth 9, 686-707.

Foley, S. F. (1992) Vein-plus-wall-rock melting mechanisms in the lithosphere and the origin of potassic alkaline magmas. Lithos 28, 435-438.

Foley, S. F., Barth, M. G. and Jenner, G. A. (2000) Rutile/melt partition coefficients for trace elements and an assessment of the influence of rutile on the trace element characteristics of subduction zone magmas. Geochim. Cosmochim. Acta 64, 933-938.

Fraser, K. J. and Hawkesworth, C. J. (1992) The petrogenesis of group 2 ultrapotassic kimberlite from Finsch mine, South Africa. Lithos 28, 327-345.

Gaffney, A. M., Blichert-Toft, J., Nelson, B. K., Bizzarro, M., Rosing, M. and Albarede, F. (2007) Constraints on sourceforming processes of West Greenland kimberlites inferred from Hf-Nd isotope systematics. Geochim. Cosmochim. Acta 71, 2820-2836.

Gale, G. H., Dabek, L. B. and Fedikow, M. A. F. (1999) The application of rare earth element analyses in the exploration for volcanogenic massive sulfide type deposits. $J$. Explor. Min. Geol. 6, 233-252.

Gregoire, M., Bell, D. R. and Le Roex, A. P. (2003) Garnet lherzolites from the Kaapvaal Craton (South Africa): trace element evidence for a metasomatic history. J. Petrol. 44, $629-657$.

Haggerty, S. E. and Birkett, T. (2004) Geological setting and chemistry of kimberlite clan rocks in the Dharwar craton, India. Lithos 76, 535-554.

Harris, M., Le Roex, A. P. and Class, C. (2004) Geochemistry of the Uintiesberg kimberlite, South Africa: petrogenesis of an offcraton, group I kimberlite. Lithos 74, 149-165.

Hart, S. R. and Davis, K. E. (1978) Nickel partitioning between olivine and silicate melt. Earth Planet. Sci. Lett. 40, 203-
219.

Hoffmann, J. E., Svahnberg, H., Piazolo, S., Scherstén, A. and Münker, C. (2012) The geodynamic evolution of Mesoarchean anorthosite complexes inferred from the Naajat Kuuat Complex, southern West Greenland. Precamb. Res. 197, 149-170.

Kaur, G. and Mitchell, R. H. (2013) Mineralogy of the P2-West 'Kimberlite', Wajrakarur kimberlite field, Andhra Pradesh, India: kimberlite or lamproite? Mineral. Mag. 77(8), 31753196.

Kempton, P. D., Harmon, R. S., Stosch, H.-G., Hoefs, J. and Hawkesworth, C. J. (1988) Open-system O-isotope behaviour and trace element enrichment in the sub-Eifel mantle. Earth Planet. Sci. Lett. 89, 273-287.

Keshav, S., Corgne, A., Gudfinnson, G. H., Bizimis, M., McDonough, W. F. and Fei, Y. (2005) Kimberlite petrogenesis: insights form clinopyroxene-melt partitioning experiments at $6 \mathrm{GPa}$ in the $\mathrm{CaO}-\mathrm{MgO}-\mathrm{Al}_{2} \mathrm{O}_{3}-\mathrm{SiO}_{2}-$ $\mathrm{CO}_{2}$ system. Geochim. Cosmochim. Acta 69, 2829-2845.

Kjarsgaard, B. A., Pearson, D. G., Tappe, S., Nowell, G. M. and Dowall, D. P. (2009) Geochemistry of hypabyssal kimberlites from Lac de Gras, Canada: Comparisons to a global database and applications to the parent magma problem. Lithos 112S, 236-248.

Klemme, S., Blundy, J. D. and Wood, B. J. (2002) Experimental constraints on major and trace element partitioning during partial melting of eclogite. Geochim. Cosmochim. Acta 66, 3109-3123.

Le Roex, A. P., Bell, D. R. and Davis, P. (2003) Petrogenesis of Group I kimberlites from Kimberley, South Africa: evidence from bulk-rock geochemistry. J. Petrol. 44, 2261-2286.

Lloyd, F. E., Edgar, A. D., Forsyth, D. M. and Barnett, R. L. (1991) The paragenesis of upper mantle xenoliths from the quaternary volcanics south east of Gees, west Eifel Germany. Mineral. Mag. 55, 95-112.

McKenzie, D. (1989) Some remarks on the movement of small melt fractions in the mantle. Earth Planet. Sci. Lett. 95, 53-72.

Mitchell, R. H. (1986) Kimberlites: Mineralogy, Geochemistry and Petrology. Plenum Press, New York, 406 pp.

Mitchell, R. H. (1995a) Kimberlites: Orangeites and Related Rocks. Plenum Press, New York, 406 pp.

Mitchell, R. H. (1995b) Melting experiments on a sanidine phlogopite lamproite at 4-7 GPa and their bearing on the sources of lamproite magmas. J. Petrol. 36, 1455-1474.

Mitchell, R. H. and Bergman, S. C. (1991) Petrology of Lamproites. Plenum Press, New York, 408 pp.

Mottl, M. J. (1983) Metabasalts, axial hot springs, and the structure of hydrothermal systems at mid ocean ridges. Geol. Soc. Amer. Bull. 94, 161-180.

Murphy, D. T., Collerson, K. D. and Kamber, B. S. (2002) Lamproites from Gaussberg, Antarctica: possible transition zone melts of Archaean subducted sediment. J. Petrol. 43, 981-1001.

Naqvi, S. M. (2005) Geology and Evolution of the Indian Plate (from Hadean to Holocene $4 \mathrm{Ga}$ to $4 \mathrm{Ka}$ ). Capital Publishers, New Delhi, 450 pp.

Patel, S. C., Ravi, S., Anilkumar, Y., Naik, A., Thakur, S. S., Pati, J. K. and Nayak, S. S. (2009) Mafic xenoliths in 
Proterozoic kimberlites from Eastern Dharwar Craton, India: Minerology and P-T regime. J. Asian Earth Sci. 34, 336-346.

Pearce, J. A. (2008) Geochemical fingerprinting of oceanic basalts with applications to ophiolite classification and the search for Archean oceanic crust. Lithos 100, 14-48.

Pearce, J. A. and Peate, D. W. (1995) Tectonic implications of the composition of volcanic arc magmas. Ann. Rev. Earth Planet. Sci. 23, 251-285.

Pearce, J. A., Kempton, P. D., Nowell, G. M. and Noble, S. R. (1999) Hf-Nd element and isotope perspective on the nature and provenance of mantle and subduction components in western pacific arc-basin system. J. Petrol. 40(11), 15791611.

Polat, A., Appel, P. W. U., Fryer, B., Windley, B., Frei, R., Samson, I. M. and Huang, H. (2009) Trace element systematics of the Neoarchean Fiskenæsset anorthosite complex and associated meta-volcanic rocks, SW Greenland: evidence for a magmatic arc origin. Precamb. Res. 175, 87115 .

Price, S. E., Russell, J. K. and Kopylova, M. G. (2000) Primitive magma from the Jericho Pipe, N.W.T., Canada: constraints on primary kimberlite melt chemistry. J. Petrol. 41, 789-808.

Ramakrishnan, M. and Vaidyanadhan, R. (2010) Geology of India, Vol. 1. Geological Society of India, Bangalore.

Rao, S. and Phadtre, P. N. (1966) Kimberlite pipe rocks of Wajrakarur. J. Geol. Soc. India 7, 55-58.

Rau, T. K., Chowdary, V. S., Reddy, N. S., Ravi, S., Sridhar, M., Bhaskar Rao, K. S. and Sinha, K. K. (2005) Excursion guide to Wajrakarur kimberlite field. Group Discussion on Kimberlites and Related Rocks of India (November 22 nd to 26th, 2005). Geological Society of India Publication, $18 \mathrm{pp}$.

Reddy, T. A. K. (1987) Kimberlite and lamproite rocks of Wajrakarur area Andhra Pradesh. J. Geol. Soc. India 30, 112.

Rombouts, L. (2003) Assessing the diamond potential of kimberlites from discovery to evaluation and bulk sampling. Min. Dep. 38, 496-504.

Smith, C. B., Gurney, J. J., Skinner, E. M. W., Clement, C. R. and Ebrahim, N. (1985) Geochemical character of the southern African kimberlites: a new approach based on isotopic constraints. Trans. Geol. Soc. South Afr. 88, 267-280.

Sparks, R. S. J. (2013) Kimberlite volcanism. Ann. Rev. Earth Planet. Sci. 41, 497-528.

Sparks, R. S. J., Brooker, R. A., Field, M., Kavanagh, J., Schumacher, J. C., Walter, M. J. and White, J. (2009) The nature of erupting kimberlite melts. Lithos 112, 429-438.

Spath, A., Le Roex, A. P. and Opiyo-Akech, N. (2001) Plumelithosphere interaction and the origin of continental riftrelated alkaline volcanism - the Chyulu Hills Volcanic Prov- ince, southern Kenya. J. Petrol. 42, 765-787.

Sun, S. S. and McDonough, W. F. (1989) Chemical and isotopic systematics of oceanic basalts: implications for mantle composition and processes. Magmatism in Ocean Basins (Saunders, A. D. and Norry, M. J., eds.), Geol. Soc. London Sp. Pub. 42, 313-345.

Szabo, C., Bodnar, R. J. and Sobolev, A. (1996) Metasomatism associated with subduction related, volatile rich silicate melt in the upper mantle beneath the Nograd-Gomor volcanic field, northern Hungary/southern Slovakia: Evidence from silicate melt inclusions. Eur. J. Mineral. 8, 881-899.

Tainton, K. M. and McKenzie, D. (1994) The generation of kimberlites, lamproites and their source rocks. J. Petrol. 35, 787-817.

Tappe, S., Foley, S. F., Jenner, G. A. and Kjarsgaard, B. A. (2005) Integrating ultramafic lamprophyres into the IUGS classification of igneous rocks: rational and implications. J. Petrol. 46(9), 1893-1900.

Tappe, S., Foley, S. F., Jenner, G. A., Heaman, L. M., Kjarsgaard, B. A., Romer, R. L., Stracke, A., Joyce, N. and Hoefs, J. (2006) Genesis of ultramafic lamprophyres and carbonatites at Aillik bay, Labradore: A consequence of incipient lithospheric thinning beneath the North Atlantic craton. J. Petrol. 47, 1261-1315.

Tappe, S., Pearson, D. G., Nowell, G. M., Nielsen, T. F. D., Milstead, P. and Muehlenbachs, K. (2011) A fresh isotopic look at Greenland kimberlites: cratonic mantle lithosphere imprint ondeep source signal. Earth Planet. Sci. Lett. 305, 235-248.

Tappe, S., Steenfelt, A. and Nielsen, T. F. N. (2012) Asthenospheric source of Neoproterozoic and Mesozoic kimberlites from the North Atlantic craton, West Greenland: new high-precision $\mathrm{U}-\mathrm{Pb}$ and $\mathrm{Sr}-\mathrm{Nd}$ isotope data on perovskite. Chem. Geol. 320-321, 113-127.

Tappe, S., Pearson, G. D., Kjarsgaard, B. A., Nowell, G. and Dowall, D. (2013) Mantle transition zone input to kimberlite magmatism near a subduction zone: Origin of anomalous $\mathrm{Nd}-\mathrm{Hf}$ isotope systematics at Las de Gras, Canada. Earth Planet. Sci. Lett., 371-372, 235-251.

Toyama, C., Muramatsu, Y., Yamamoto, J., Nakai, S. I. and Kaneoka, I. (2012) Sr and Nd isotope ratios and trace element concentrations in kimberlites from Shadong and Liaoning (China) and the Kimberley area (South Africa). Geochem. J. 46, 45-59.

Ulmer, P. and Sweeney, R. J. (2002) Generation and differentiation of group II kimberlites: constraints from a highpressure experimental study to $10 \mathrm{GPa}$. Geochim. Cosmochim. Acta 66, 2139-2153.

Wyllie, P. J. (1987) Discussion of recent papers on carbonated peridotite, bearing on mantle metasomatism and magmatism. Earth Planet. Sci. Lett. 82, 391-397. 